\title{
Chemical Constituents from Branches of Maytenus gonoclada (Celastraceae) and Evaluation of Antimicrobial Activity
}

\author{
Fernando C. Silva, ${ }^{a, c}$ Lucienir P. Duarte, ${ }^{*, a}$ Grácia D. F. Silva, ${ }^{a}$ Sidney A. V. Filho, ${ }^{a, b}$ \\ Ivana S. Lula, ${ }^{a}$ Jacqueline A. Takahashi ${ }^{c}$ and William S. T. Sallum ${ }^{c}$
}
${ }^{a}$ Núcleo de Estudos de Plantas Medicinais and 'Laboratório de Biotecnologia e Bioensaios, Departamento de Química, Universidade Federal de Minas Gerais, Av. Antônio Carlos, 6627, 31270-901 Belo Horizonte-MG, Brazil

${ }^{b}$ Escola de Farmácia, Universidade Federal de Ouro Preto, Rua Costa Sena, 171, 35400-000 Ouro Preto-MG, Brazil

\begin{abstract}
Seis triterpenos pentacíclicos isolados dos galhos de Maytenus gonoclada (Celastraceae), incluindo todos os dados de RMN do novo composto 3-oxo-12 $\alpha$,29-diidroxifriedelano são aqui relatados. A estereoquímica do novo friedelano foi estabelecida por dados de RMN bidimensional (HSQC, HMBC e NOESY), e sua massa molecular confirmada por espectrometria de massas (ESI). Testes de atividade antimicrobiana usando método de difusão em disco e de macrodiluição foram realizados contra as bactérias Escherichia coli, Citrobacter freundii e Bacillus cereus, e contra o fungo Candida albicans. O triterpeno 3-oxo-12 $\alpha$-hidroxifriedelano mostrou resultado positivo contra C. albicans.
\end{abstract}

Six pentacyclic triterpenes were isolated from branches of Maytenus gonoclada (Celastraceae) and all NMR data of a new compound 3-oxo-12 $\alpha, 29$-dihydroxyfriedelane are herein reported. The stereochemistry of the new friedelane was established by bidimensional NMR (HSQC, HMBC and NOESY) data, and its molecular weight confirmed by ESI mass spectrometry. Antimicrobial activity assays using the method of disk diffusion and macrodilution were carried out against the bacteria Escherichia coli, Citrobacter freundii, and Bacillus cereus, and against the fungi Candida albicans. The triterpene 3-oxo-12 $\alpha$-hydroxyfriedelane showed positive result against C. albicans.

Keywords: Maytenus gonoclada, Celastraceae, 3-oxo-12 $\alpha$-hydroxyfriedelane, 3-oxo-12 $\alpha, 29$ dihydroxyfriedelane, antimicrobial activity

\section{Introduction}

Celastraceae family contains many species that have been extensively studied in function of their use in traditional medicine. Some species of Maytenus genus are worldwide distributed and have been used by Africans to treat cancer, by Asian people as an insecticide, ${ }^{1}$ and by the South American people on the treatment of gastrointestinal diseases. ${ }^{2}$ The biological activities associated to Maytenus species have been assigned to different classes of secondary metabolites such as phenolic glucosides, ${ }^{3}$ flavonoids ${ }^{4}$ and triterpenes. ${ }^{5}$

Pentacyclic triterpenes (PCTT) have been commonly isolated from species of the Celastraceae family, and some

*e-mail: lucienir@ufmg.br of them, like 3-oxofriedelane and 3 $\beta$-hydroxyfriedelane, are considered taxonomic markers of Maytenus genus. ${ }^{4}$ A large number of pharmacological activities has been associated to triterpenes isolated from species of the Maytenus genus, such as, 3,15-dioxo-21 $\alpha$ hydroxyfriedelane, isolated from Maytenus robusta, that showed antiulcerogenic activity, ${ }^{6}$ and maytenfolic acid, isolated from Maytenus heterophylla, that showed growth inhibitory effect on Candida albicans. ${ }^{7}$

Maytenus gonoclada Martius, popularly known as "tiuzinho", can be found in regions of "cerrado" and rupestrian fields of Southeastern and Northeastern Brazil. In our previous studies of the hexane extract from M. gonoclada leaves, the occurrence of five PCTT of the friedelane series was reported. ${ }^{8}$ 
The present paper reports the phytochemical study of hexane extract from branches of $M$. gonoclada, which was isolated five known triterpenes: 3-oxofriedelane (1), $3 \beta$-hydroxyfriedelane (2), 3-oxo-12 $\alpha$-hydroxyfriedelane (3), 3,11-dioxofriedelane (4) and 3,16-dioxofriedelane (5). ${ }^{8}$ In addition, a new compound of the friedelane series, 3 -oxo-12 $\alpha, 29$-dihydroxyfriedelane (6), was also isolated and its structure was developed by detailed ${ }^{1} \mathrm{H}$ and ${ }^{13} \mathrm{C}$ NMR analysis, including bidimensional (HSQC, HMBC and NOESY) spectral data.

The NMR data of compound $\mathbf{6}$, as well as the complete hydrogen chemical shifts assigned to compound $\mathbf{5}$, that have not been described in the literature yet, are herein reported for the first time.

An evaluation of the antimicrobial activity of the hexane extract is also reported here. The compounds 3 -oxofriedelane (1), 3-oxo-12 $\alpha$-hydroxyfriedelane (3), 3,16-dioxofriedelane (5) and 3-oxo-12 $\alpha, 29$ dihydroxyfriedelane (6) were screened by the methods of disk diffusion and macrodilution. The assays were based on the growth inhibition of standard strains of Escherichia coli, Citrobacter freundii, Bacillus cereus, and the yeast Candida albicans. Minimal inhibitory concentration (MIC), produced by hexane extract and 3-oxo-12 $\alpha$ hydroxyfriedelane (3) were determined. The results showed that 3-oxo-12 $\alpha$-hydroxyfriedelane (3) presented growth inhibition activity.

\section{Experimental}

\section{General experimental procedures}

Column chromatography (CC) was carried out using silica gel 60 (70-230 Mesh, Merck) and for thin layer chromatography (TLC) it was employed precoated silica gel plates. The detection of spots was made by spraying a mixture (1:1) of vanillin (ethanol solution, $1 \% \mathrm{~m} / \mathrm{v}$ ) and perchloric acid (aqueous solution, $3 \%$ v/v). ${ }^{9}$ A Mettler FP 80 HT apparatus was used to determine melting points (uncorrected). Elemental analyses were performed on a CHN Perkin-Elmer 2400 apparatus. Optical rotations were measured on a Perkin-Elmer model 341 polarimeter using a $100 \mathrm{~mm}, 1.0 \mathrm{~mL}$ cell tube capacity. Infrared spectra were recorded on a Perkin Elmer, Spectrum One spectrophotometer (ATR). Mass spectrometry was conducted in a LCQFleet (Thermo Scientific, San Jose, CA) bearing an electrospray ionization (ESI) source, operating in the positive mode. ESI source conditions were: heated capillary temperature of $290^{\circ} \mathrm{C}$, sheath gas $\left(\mathrm{N}_{2}\right)$ flow rate at 20 (arbitrary units), spray voltage of $4.8 \mathrm{kV}$, and capillary voltage of $2.0 \mathrm{~V}$.
The ${ }^{1} \mathrm{H}$ and ${ }^{13} \mathrm{C}$ NMR spectra were measured on a Bruker DRX 400 Avance spectrometer at 400 and $100 \mathrm{MHz}$ at $300 \mathrm{~K}$, equipped with inverse detection $5 \mathrm{~mm}$ multinuclear head ${ }^{1} \mathrm{H} /{ }^{13} \mathrm{C}$. Each compound was dissolved in $\mathrm{CDCl}_{3}$ or in $\mathrm{CDCl}_{3}$ with 2 drops of pyridine- $d_{5}$, and transferred to a $5 \mathrm{~mm}$ o.d. NMR tube. TMS was used as internal standard $\left(\delta_{\mathrm{H}}=\delta_{\mathrm{C}}=0\right)$. Bi-dimensional (2D) NMR spectra were acquired under standard conditions. Data processing was carried out on SGI workstation using the Bruker (DRX 400) software.

\section{Plant material}

Samples of M. gonoclada's branches were collected in Serra da Piedade, Caeté, Minas Gerais, Brazil, in October 2004. Botanical identification was provided by Dr. Rita Maria Carvalho-Okano. The voucher specimen (HBCB 60280) was deposited in the Herbarium of the Universidade Federal de Minas Gerais, Belo Horizonte, Minas Gerais, Brazil.

\section{Extraction and isolation}

The branches of $M$. gonoclada were dried at room temperature, milled and the resulting powder (1000 g) was submitted to extraction with hexane in a Soxhlet apparatus. The formation of a white solid material was observed during the removal of the hexane in a rotatory evaporator. This solid was separated by filtration; the dried material $(1.0 \mathrm{~g})$ was submitted to silica gel $(50 \mathrm{~g}) \mathrm{CC}$ eluted with hexane, chloroform, ethyl acetate and ethanol in mixtures of increasing polarity. Fifty-seven fractions of $200 \mathrm{~mL}$ each were obtained and grouped according to the similar profiles observed in the chromatoplates. Fractions 22 to 37 were eluted with hexane-chloroform (1:1). After solvent evaporation, fraction (Fr.) 22 produced a white solid (5.0 mg), which was identified as 3-oxofriedelane (1). Fractions 23-27 provided a white solid (112.2 $\mathrm{mg}$ ), which was rechromatographed furnishing additional amount $(35.0 \mathrm{mg}$ ) of 3-oxofriedelane (1) and 3 $\beta$-hydroxyfriedelane (2) $(15.2 \mathrm{mg})$. These PCTTs were characterized by their respective ${ }^{13} \mathrm{C}$ NMR spectral data, being also compared to published data. Fractions $34-35$ gave a white solid (34.4 mg) that was identified by NMR spectra analyses and comparison with published data as a mixture of 3,11-dioxofriedelane (4) and 3,16-dioxofriedelane (5). The group of fractions Fr.36-37 (234.0 mg) was determined as a mixture, by TLC, and named as material A. The group Fr.38-43 (173.2 mg) (eluted from hexane/chloroform 3:7) was submitted to flash CC (silica gel 230-400 Mesh, Merck, $5.8 \mathrm{~g}$ ) eluted with hexane, chloroform, ethyl 
acetate and methanol in mixtures of increasing polarity. Forty-seven fractions of $10 \mathrm{~mL}$ each were obtained yielding the 3-oxo-12 $\alpha$-hydroxyfriedelane (3) (10.3 mg) and 3,16-dioxofriedelane (5) (12.0 mg). Using TLC, the fraction $56(56.2 \mathrm{mg})$ (eluted with ethyl acetate) was also characterized as a mixture, and then named as material B.

Material A (234.0 mg) was submitted to silica gel CC (10 g) eluted with pure hexane, chloroform and ethyl acetate, or in mixtures of increasing polarities, providing 73 fractions of $25 \mathrm{~mL}$ each. After solvent removal, Fr.A25 (eluted from hexane/chloroform 7:3) gave a white solid (14.1 mg) which was identified as 3,11-dioxofriedelane (4), and Fr.A27 (eluted from hexane/chloroform 7:3) (10.0 mg) was identified as 3,16-dioxofriedelane (5). The group of fractions A30-45 eluted from hexane/chloroform 1:1 was purified by recrystallization (ethanol with drops of acetone) producing a crystalline solid $(32.6 \mathrm{mg})$, which was identified as 3-oxo-12 $\alpha$-hydroxyfriedelane (3).

Material B (56.2 mg) was submitted to silica gel CC (22.6 g) eluted initially with chloroform/ethyl acetate (1:1) and then with pure ethyl acetate, furnishing 75 fractions of $10 \mathrm{~mL}$ each. After solvent evaporation, Fr.B49-69 gave an amorphous solid $(9.0 \mathrm{mg})$ that was identified as 3-oxo$12 \alpha, 29$-dihydroxyfriedelane (6).

\section{3,16-Dioxofriedelane (5)}

Amorphous white solid, mp 218-220 C. NMR spectral data: See Table 1.

\section{3-Oxo-120,29-dihydroxyfriedelane (6)}

Amorphous white solid, $[\alpha]_{\mathrm{D}}^{20}=-23\left(\mathrm{CHCl}_{3}\right), \mathrm{mp}$ 250-254 ${ }^{\circ} \mathrm{C}$. IR (ATR) $v_{\max } / \mathrm{cm}^{-1}: 3327,2920-2850,1712$, 1455, 1389, 1294, 1245, 1218, 1204, 1170, 111, 1056, 1039, 999, 977, 918, 823 and 751. NMR spectral data: See Table 1. MS ((+)-ESI): $m / z, 423.35$ (24\%) $\left[\mathrm{M}+\mathrm{H}-2 \mathrm{H}_{2} \mathrm{O}\right]$; $405.33(100 \%)$.

\section{Antimicrobial bioassays}

The bacteria strains, E. coli ATCC 25723, B. cereus ATCC 11778, C. freundii ATCC 29935 and the yeast $C$. albicans ATCC 18804 used in this study were obtained from American Type Culture Collection. The media broth heart infusion (BHI) was purchased from Merck (Darmstadt, Germany) and Biobrás (Montes Claros, Brazil). The strains were maintained on BHI medium and refrigerated at $7{ }^{\circ} \mathrm{C}$.

Antimicrobial activity was evaluated using the disk diffusion method, according to the literature. ${ }^{10}$ The microorganisms were cultivated in medium BHI and incubated for $18 \mathrm{~h}$ at $37{ }^{\circ} \mathrm{C}$. Cells were suspended, according to the McFarland protocol, in saline solution to produce a suspension containing approximately $5 \times 10^{5} \mathrm{CFU} \mathrm{mL} \mathrm{mL}^{-1}$. An aliquot $(10 \mu \mathrm{L})$ of this suspension was added to $10 \mathrm{~mL}$ of sterile antibiotic agar at $40{ }^{\circ} \mathrm{C}$ and then, inside a laminar flow cabinet, this mixture was poured onto an agar plate. Each tested compound $(100 \mu \mathrm{g})$ was dissolved in chloroform and put on a paper disk $(6 \mathrm{~mm}$ diameter), that was dried and placed on the agar plate. Each plate was constituted by 5 sample/disk, together with a disk containing chloramphenicol $(30 \mu \mathrm{g})$ and another containing only chloroform that were used as positive and negative controls, respectively. The susceptibility of the bacteria and the yeast was determined by the formation of a growth inhibitory zone ( $\mathrm{mm}$ ) of each extract and tested compounds, observed after $18 \mathrm{~h}$ of incubation at $37{ }^{\circ} \mathrm{C}$. Experiments were run in triplicate, and the results are presented as mean values of the three measurements. Chloramphenicol and miconazole were purchased from Sigma Chemical Co. (St. Louis, MO). The broth dilution test was used to evaluate the minimum inhibitory concentration (MIC) of growth and the initial inoculums contained $5 \times 10^{5} \mathrm{CFU} \mathrm{mL}{ }^{-1} .{ }^{11}$ Tested compounds were dissolved in dimethyl sulfoxide (DMSO). Sequential dilutions provided the final concentrations of $512,256,128,64,32,16,8,4,2$, and $1 \mu \mathrm{g} / \mathrm{mL}$ of tested compounds in BHI medium. Then, $100 \mu \mathrm{L}$ of the inoculum was added to each tube. After an incubation time of $18 \mathrm{~h}$ at $37{ }^{\circ} \mathrm{C}$, the lowest concentration of the tested compounds that inhibited the microorganisms growth (MIC) was visually determined. Tests using DMSO as negative control and chloramphenicol (for bacteria) and miconazole (for Candida) as positive controls were carried out in parallel. MIC tests were performed in duplicate with full agreement between both results.

\section{Results and Discussion}

A new triterpene (3-oxo-12 $\alpha, 29$-dihydroxyfriedelane, 6) and five known compounds (Figure 1) were isolated from the phytochemical study of the hexane extract of M. gonoclada branches. The known compounds were isolated in high degree of pureness and they were respectively identified as 3-oxofriedelane (1), ${ }^{12,13}$ $3 \beta$-hydroxyfriedelane (2), ${ }^{14} 3$-oxo-12 $\alpha$-hydroxyfriedelane (3), ${ }^{8}$ 3,11-dioxofriedelane (4), ${ }^{15}$ 3,16-dioxofriedelane (5). ${ }^{12,16}$ For the identification, their physical and spectral data were analyzed and the results compared with previously published data.

Compound 5 was isolated from hexane extract as a white amorphous solid, mp 218-220 ${ }^{\circ} \mathrm{C}$, and showed positive Liebermann-Burchard (LB) test for triterpenes. ${ }^{17}$ The carbon signals attributed to compound $\mathbf{5}$ were in accordance with the reported data. ${ }^{12,16}$ Through $2 \mathrm{D}$ NMR 


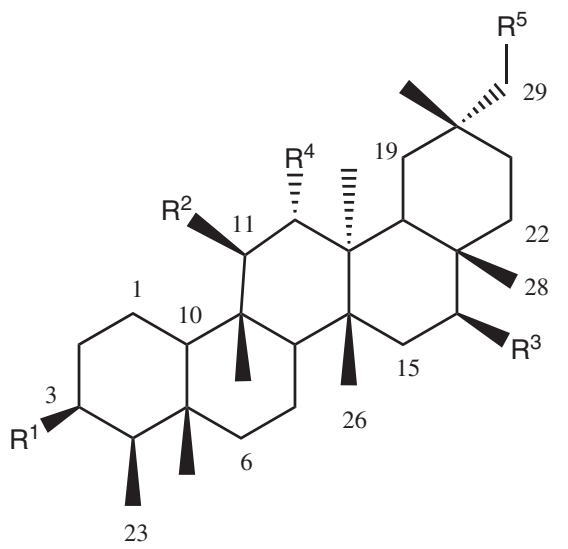

\begin{tabular}{cccccc}
\hline Compd. & $\mathrm{R}^{1}$ & $\mathrm{R}^{2}$ & $\mathrm{R}^{3}$ & $\mathrm{R}^{4}$ & $\mathrm{R}^{5}$ \\
\hline $\mathbf{1}$ & $=\mathrm{O}$ & $\mathrm{H}$ & $\mathrm{H}$ & $\mathrm{H}$ & $\mathrm{H}$ \\
$\mathbf{2}$ & $\mathrm{HO}$ & $\mathrm{H}$ & $\mathrm{H}$ & $\mathrm{H}$ & $\mathrm{H}$ \\
$\mathbf{3}$ & $=\mathrm{O}$ & $\mathrm{H}$ & $\mathrm{H}$ & $\mathrm{OH}$ & $\mathrm{H}$ \\
$\mathbf{4}$ & $=\mathrm{O}$ & $=\mathrm{O}$ & $\mathrm{H}$ & $\mathrm{H}$ & $\mathrm{H}$ \\
$\mathbf{5}$ & $=\mathrm{O}$ & $\mathrm{H}$ & $=\mathrm{O}$ & $\mathrm{H}$ & $\mathrm{H}$ \\
$\mathbf{6}$ & $=\mathrm{O}$ & $\mathrm{H}$ & $\mathrm{H}$ & $\mathrm{HO}$ & $\mathrm{HO}$
\end{tabular}

Figure 1. Chemical structures of the triterpenes isolated from branches of M.gonoclada.

spectral data (HSQC, HMBC and NOESY), the chemical shifts of all hydrogens assigned to compound $\mathbf{5}$ as well as its correlations were fully established (Figure 2 and Table 1). To the best of our knowledge, it is the first time that these data are reported.

Compound 6 (Figure 2) was obtained as an amorphous white solid, mp 250-254 $\left.{ }^{\circ} \mathrm{C},[\alpha]_{\mathrm{D}}^{20}-23, \mathrm{CHCl}_{3}\right]$, and showed positive LB test for triterpenes. ${ }^{17}$ The elemental analysis of compound $\mathbf{6}$ presented $\mathrm{C} 78.54 \%$ and $\mathrm{H}$ $10.97 \%$, compatible with the molecular formula $\mathrm{C}_{30} \mathrm{H}_{50} \mathrm{O}_{3}$ (MW $458 \mathrm{~g} \mathrm{~mol}^{-1}$; calculated: C 78.55\%; H 10.99\%). ESI mass spectrometry confirmed this molecular weight, presenting a fragment $\mathrm{m} / \mathrm{z} 423.35(24 \%)$ [M $\left.+\mathrm{H}-2 \mathrm{H}_{2} \mathrm{O}\right]$. This type of fragmentation is described for PCTT. According to Rhourri-Frih, ${ }^{18}$ in PCTTs like betulin, the loss of two molecules of water occurs due to the presence of two hydroxyl groups, as observed for compound $\mathbf{6}$. The IR spectra of 6 showed absorption bands: at $3327 \mathrm{~cm}^{-1}$, compatible with the presence of hydroxyl group; at 2920 and $2850 \mathrm{~cm}^{-1}$, characteristic of the alicyclic hydrocarbon; and also at $1712 \mathrm{~cm}^{-1}$, which was attributed to a carbonyl group. The ${ }^{13} \mathrm{C}$ NMR and DEPT 135 spectra showed 30 signals: seven primary, eleven secondary, five tertiary and seven quaternary carbons, which were according to the PCTT skeleton. The ${ }^{1} \mathrm{H}$ and ${ }^{13} \mathrm{C}$ NMR data indicated the compound $\mathbf{6}$ as friedelane derivative, ${ }^{8}$ containing two hydroxyl groups.

The ${ }^{1} \mathrm{H}$ NMR spectrum of $\mathbf{6}$ showed hydrogen signals at $\delta_{\mathrm{H}} 0.70(\mathrm{~s}), \delta_{\mathrm{H}} 0.93(\mathrm{~s}), \delta_{\mathrm{H}} 0.97(\mathrm{~s}), \delta_{\mathrm{H}} 1.01(\mathrm{~s}), \delta_{\mathrm{H}} 1.17(\mathrm{~s})$, $\delta_{\mathrm{H}} 1.18(\mathrm{~s})$ and $\delta_{\mathrm{H}} 0.87(\mathrm{~d} ; J 7.0 \mathrm{~Hz})$ that were associated to seven methyl groups. According to the literature, ${ }^{8}$ the doublet at $\delta_{\mathrm{H}} 0.87$ is consistent with methyl group $\mathrm{H}-23$ of members of the friedelane series.

In the ${ }^{1} \mathrm{H}$ NMR spectrum, the hydrogen signals at $\delta_{\mathrm{H}} 3.12(\mathrm{~d} ; J 11.2 \mathrm{~Hz})$ and $\delta_{\mathrm{H}} 3.64(\mathrm{~d} ; J 11.2 \mathrm{~Hz})$ were observed. Correlations of these signals with the signal of C-29 $\left(\delta_{\mathrm{C}} 71.6\right)\left(\mathrm{CH}_{2}\right)$ were observed in the HSQC contour map. The chemical shifts in this NMR region are typical of carbons attached to hydroxyl group, ${ }^{14,16,19}$ suggesting the existence of hydroxyl group attached to C-29. Correlations observed in the HMBC contour map, among the signal of $\mathrm{H}-29$ with signals of C-19 and C-30, confirmed the presence

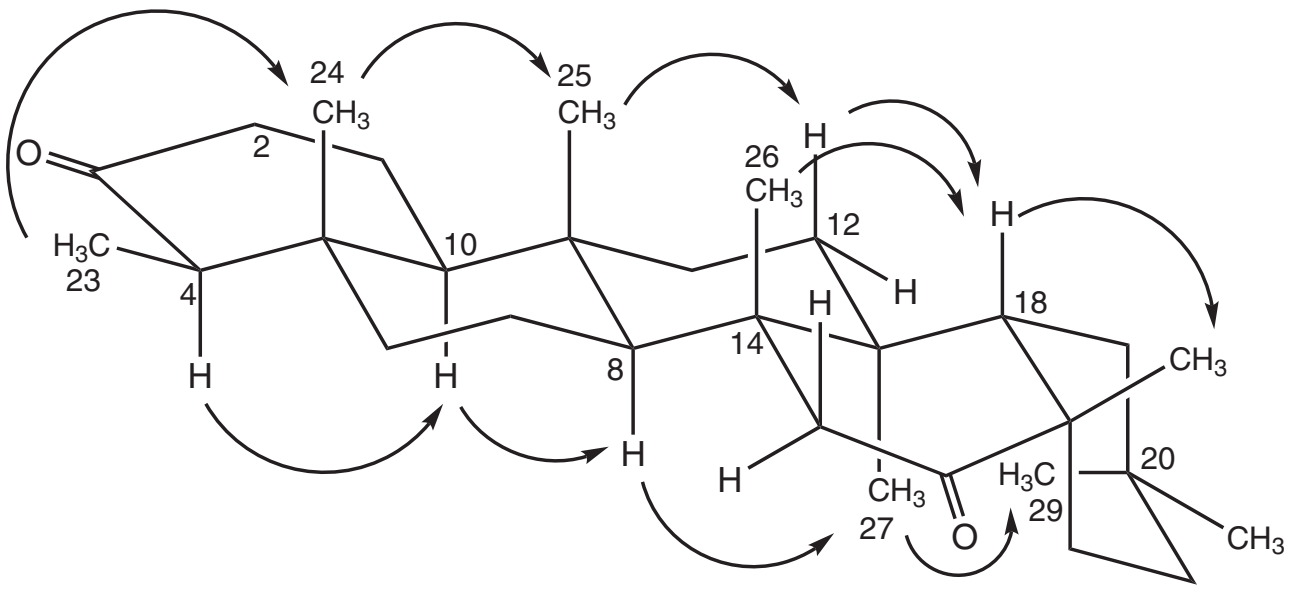

Figure 2. NOESY correlations observed for 3,16-dioxofriedelane (5). 
Table 1. ${ }^{1} \mathrm{H}$ and ${ }^{13} \mathrm{C}$ NMR spectral data of 3,16-dioxofriedelane (5) and 3-oxo-12 $\alpha, 29$-dihydroxyfriedelane (6)

\begin{tabular}{|c|c|c|c|c|c|c|}
\hline \multirow[b]{2}{*}{ entry } & \multicolumn{3}{|c|}{ Triterpene $\mathbf{5}$} & \multicolumn{3}{|c|}{ Triterpene $\mathbf{6}$} \\
\hline & DEPT & $\delta_{\mathrm{C}}$ & $\delta_{\mathrm{H}}$ & DEPT & $\delta_{\mathrm{C}}$ & $\delta_{\mathrm{H}}$ \\
\hline 1 & $\mathrm{CH}_{2}$ & 22.2 & $\begin{array}{l}1.69 \mathrm{ax} ; \mathrm{m} \\
1.96 \mathrm{eq} ; \mathrm{m}\end{array}$ & $\mathrm{CH}_{2}$ & 22.3 & $\begin{array}{l}1.67 \mathrm{ax} ; \mathrm{m} \\
1.93 \mathrm{eq} ; \mathrm{m}\end{array}$ \\
\hline 2 & $\mathrm{CH}_{2}$ & 41.4 & $\begin{array}{l}2.30 \mathrm{eq} ; \mathrm{m} \\
2.39 \mathrm{ax} ; \mathrm{m}\end{array}$ & $\mathrm{CH}_{2}$ & 41.4 & $\begin{array}{l}2.26 \text { ax; dd; } J 3.2 \text { and } 14.6 \\
2.35 \text { eq; dd; } J 6.2 \text { and } 14.6\end{array}$ \\
\hline 3 & $\mathrm{C}$ & 212.7 & - & $\mathrm{C}$ & 212.7 & - \\
\hline 4 & $\mathrm{CH}$ & 58.1 & $2.24 ; \mathrm{m}$ & $\mathrm{CH}$ & 58.1 & $2.22 ; \mathrm{d} ; J 7.0$ \\
\hline 5 & $\mathrm{C}$ & 42.1 & - & $\mathrm{C}$ & 41.8 & - \\
\hline 6 & $\mathrm{CH}_{2}$ & 40.9 & $\begin{array}{l}1.25 \mathrm{ax} ; \mathrm{m} \\
1.77 \mathrm{eq} ; \mathrm{m}\end{array}$ & $\mathrm{CH}_{2}$ & 41.1 & $\begin{array}{l}1.26 \mathrm{ax} ; \mathrm{m} \\
1.75 \mathrm{eq} ; \mathrm{m}\end{array}$ \\
\hline 7 & $\mathrm{CH}_{2}$ & 18.6 & $\begin{array}{l}1.38 \mathrm{eq} ; \mathrm{m} \\
1.46 \mathrm{ax} ; \mathrm{m}\end{array}$ & $\mathrm{CH}_{2}$ & 18.3 & $\begin{array}{l}1.35 \mathrm{eq} ; \mathrm{m} \\
1.53 \mathrm{ax} ; \mathrm{m}\end{array}$ \\
\hline 8 & $\mathrm{CH}$ & 52.3 & $1.46 ; \mathrm{m}$ & $\mathrm{CH}$ & 51.3 & $1.37 ; \mathrm{m}$ \\
\hline 9 & $\mathrm{C}$ & 37.6 & - & $\mathrm{C}$ & 38.3 & - \\
\hline 10 & $\mathrm{CH}$ & 59.2 & $1.55 ; \mathrm{m}$ & $\mathrm{CH}$ & 59.3 & $1.57 ; \mathrm{m}$ \\
\hline 11 & $\mathrm{CH}_{2}$ & 35.3 & $1.56 ; \mathrm{m}$ & $\mathrm{CH}_{2}$ & 47.0 & $\begin{array}{l}1.34 \mathrm{ax} ; \mathrm{m} \\
1.75 \mathrm{eq} ; \mathrm{m}\end{array}$ \\
\hline 12 & $\mathrm{CH}$ & 29.0 & $1.43 ; \mathrm{m}$ & $\mathrm{CH}$ & 72.1 & $3.94 ; \mathrm{dd} ; J 4.4$ and 11.2 \\
\hline 13 & $\mathrm{C}$ & 39.1 & - & $\mathrm{C}$ & 44.8 & - \\
\hline 14 & $\mathrm{C}$ & 40.4 & - & $\mathrm{C}$ & 41.1 & - \\
\hline 15 & $\mathrm{CH}_{2}$ & 50.1 & $\begin{array}{l}2.06 \mathrm{eq} ; \mathrm{m} \\
2.39 \mathrm{ax} ; \mathrm{m}\end{array}$ & $\mathrm{CH}_{2}$ & 31.6 & $1.44 ; \mathrm{m}$ \\
\hline 16 & $\mathrm{C}$ & 219.0 & - & $\mathrm{CH}_{2}$ & 35.9 & $1.54 ; \mathrm{m}$ \\
\hline 17 & $\mathrm{C}$ & 45.3 & - & $\mathrm{C}$ & 31.3 & - \\
\hline 18 & $\mathrm{CH}$ & 43.9 & $2.08 ; \mathrm{m}$ & $\mathrm{CH}$ & 44.3 & $1.94 \mathrm{~m}$ \\
\hline 19 & $\mathrm{CH}_{2}$ & 35.4 & $\begin{array}{l}1.23 \mathrm{eq} ; \mathrm{m} \\
1.34 \mathrm{ax} ; \mathrm{m}\end{array}$ & $\mathrm{CH}_{2}$ & 31.7 & $\begin{array}{l}2.26 \text { eq; } \mathrm{m} \\
1.75 \mathrm{ax} ; \mathrm{m}\end{array}$ \\
\hline 20 & $\mathrm{C}$ & 27.6 & - & $\mathrm{C}$ & 33.3 & - \\
\hline 21 & $\mathrm{CH}_{2}$ & 31.6 & $1.48 ; \mathrm{m}$ & $\mathrm{CH}_{2}$ & 29.9 & $\begin{array}{l}1.40 \mathrm{ax} ; \mathrm{m} \\
1.26 \mathrm{eq} ; \mathrm{m}\end{array}$ \\
\hline 22 & $\mathrm{CH}_{2}$ & 30.7 & $1.72 ; \mathrm{m}$ & $\mathrm{CH}_{2}$ & 38.1 & $\begin{array}{l}0.96 \text { eq; } \mathrm{m} \\
1.75 \mathrm{ax} ; \mathrm{m}\end{array}$ \\
\hline 23 & $\mathrm{CH}_{3}$ & 6.8 & $0.88 ; \mathrm{d} ; J 6.8$ & $\mathrm{CH}_{3}$ & 6.8 & $0.87 ; \mathrm{d} ; J 7.0$ \\
\hline 24 & $\mathrm{CH}_{3}$ & 14.6 & $0.74 ; \mathrm{s}$ & $\mathrm{CH}_{3}$ & 14.6 & $0.70 ; \mathrm{s}$ \\
\hline 25 & $\mathrm{CH}_{3}$ & 17.3 & $0.90 ; \mathrm{s}$ & $\mathrm{CH}_{3}$ & 19.2 & $0.93 ; \mathrm{s}$ \\
\hline 26 & $\mathrm{CH}_{3}$ & 20.3 & $1.20 ; \mathrm{s}$ & $\mathrm{CH}_{3}$ & 18.7 & $0.97 ; \mathrm{s}$ \\
\hline 27 & $\mathrm{CH}_{3}$ & 16.2 & $0.89 ; \mathrm{s}$ & $\mathrm{CH}_{3}$ & 11.6 & $1.17 ; \mathrm{s}$ \\
\hline 28 & $\mathrm{CH}_{3}$ & 27.3 & $1.30 ; \mathrm{s}$ & $\mathrm{CH}_{3}$ & 31.7 & $1.18 ; \mathrm{s}$ \\
\hline 29 & $\mathrm{CH}_{3}$ & 31.0 & $1.05 ; \mathrm{s}$ & $\mathrm{CH}_{2}$ & 71.6 & $\begin{array}{l}3.12 \mathrm{a} ; \mathrm{d} ; J 11.2 \\
3.64 \mathrm{~b} ; \mathrm{d} ; J 11.2\end{array}$ \\
\hline 30 & $\mathrm{CH}_{3}$ & 35.2 & $0.96 ; \mathrm{s}$ & $\mathrm{CH}_{2}$ & 29.2 & $1.01 ; \mathrm{s}$ \\
\hline
\end{tabular}

$\left(\delta\right.$ values in ppm, $\left.J \mathrm{~Hz}, \mathrm{CDCl}_{3}\right)$.

of a hydroxyl attached to C-29. By comparison of spectral data of $\mathbf{6}$ with similar skeleton reported in the literature, ${ }^{8}$ it was also possible to locate the signal of $\mathrm{C}-12\left(\delta_{\mathrm{C}} 72.1\right)$ and observe, in $\mathrm{HMBC}$ map, correlations of $\mathrm{H}-12$ with C-27 $\left(\delta_{\mathrm{C}} 11.6\right)$.

The detailed analysis of 2D NMR spectra and comparison with literature ${ }^{8}$ allowed the assignment of all ${ }^{1} \mathrm{H}$ and ${ }^{13} \mathrm{C}$ chemical data of triterpene $\mathbf{6}$. The following sequence of long range correlations (HMBC), H-23 $\left(\delta_{\mathrm{H}} 0.87\right) \leftrightarrow$ $\mathrm{C}-5\left(\delta_{\mathrm{C}} 41.8\right) \leftrightarrow \mathrm{H}-24\left(\delta_{\mathrm{H}} 0.70\right) \leftrightarrow \mathrm{C}-10\left(\delta_{\mathrm{C}} 59.3\right) \leftrightarrow$ $\mathrm{H}-25\left(\delta_{\mathrm{H}} 0.93\right) \leftrightarrow \mathrm{C}-8\left(\delta_{\mathrm{C}} 51.3\right) \leftrightarrow \mathrm{H}-26\left(\delta_{\mathrm{H}} 0.97\right) \leftrightarrow \mathrm{C}-13$
$\left(\delta_{\mathrm{C}} 44.8\right) \leftrightarrow \mathrm{H}-27\left(\delta_{\mathrm{H}} 1.17\right) \leftrightarrow \mathrm{C}-18\left(\delta_{\mathrm{C}} 44.3\right) \leftrightarrow \mathrm{H}-28\left(\delta_{\mathrm{H}} 1.18\right)$ was consistent with a friedelane type triterpene skeleton. ${ }^{12,14,16,19}$

The stereochemistry of triterpene $\mathbf{6}$ was established by means of data obtained from NOESY spectrum. It was possible to observe nOe correlations between $\mathrm{H}-23$ and $\mathrm{H}-4 \mathrm{ax}, \mathrm{H}-2 \mathrm{eq}, \mathrm{H}-6 \mathrm{eq}$ and $\mathrm{H}-24$. nOe effects were also observed between $\mathrm{H}-24$ and $\mathrm{H}-1 \mathrm{ax}, \mathrm{H}-6 \mathrm{eq}$ and $\mathrm{H}-25$, between H-25 and H-11eq and H-12ax. By these NOESY correlations the establishment of a chair conformation for rings $\mathrm{B}$ and $\mathrm{C}$ (Figure 3 ) was enabled. 


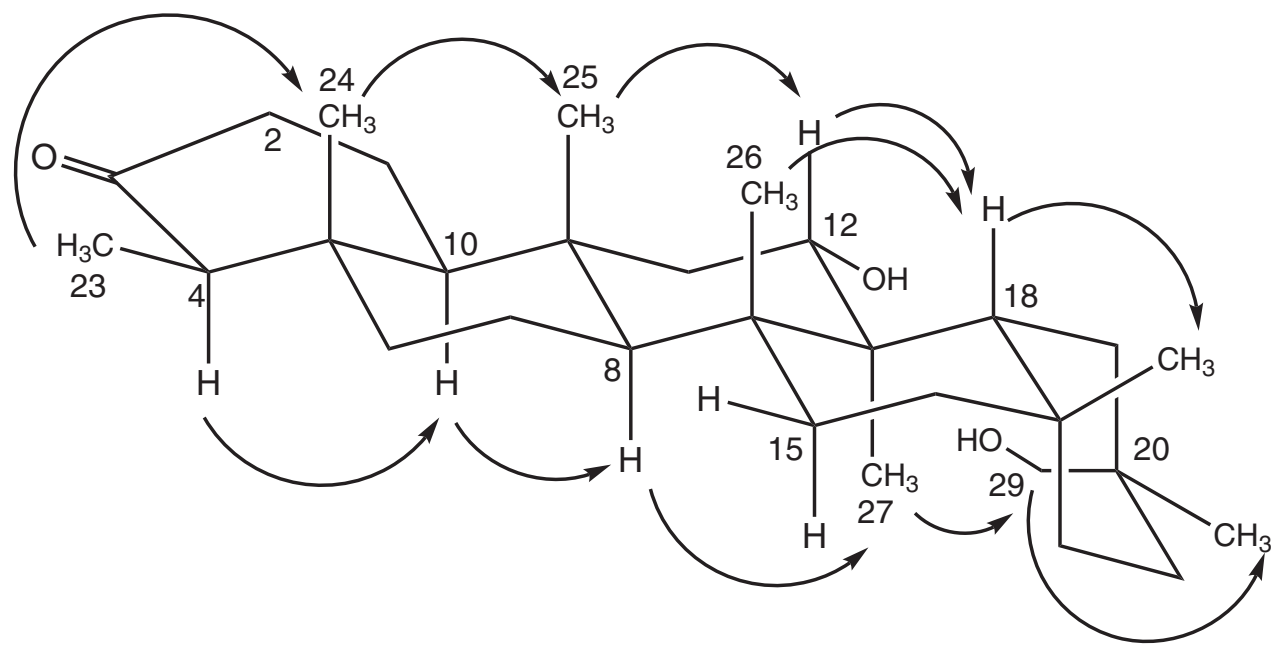

Figure 3. NOESY correlations observed for 3-oxo-12 $\alpha, 29$-dihydroxyfriedelane (6).

In the NOESY contour map, it was observed that the signal of $\mathrm{H}-18\left(\delta_{\mathrm{H}} 1.94\right)$ is correlated with the signals of $\mathrm{H}-12 \mathrm{ax}\left(\delta_{\mathrm{H}} 3.94\right)$ and $\mathrm{H}-26\left(\delta_{\mathrm{H}} 0.97\right)$. The H-12 $\left(\delta_{\mathrm{H}} 3.94\right)$ showed correlations between the signals of $\mathrm{H}-25\left(\delta_{\mathrm{H}} 0.93\right)$ and $\mathrm{H}-26\left(\delta_{\mathrm{H}} 0.97\right)$, indicating that $\mathrm{H}-12$ is in axial position, and consequently the ring $\mathrm{D}$ of this new friedelane structure is in a chair conformation. Other evidence that confirms this hypothesis is the correlation between H-8 $\left(\delta_{\mathrm{H}} 1.37\right)$ with $\mathrm{H}-27\left(\delta_{\mathrm{H}} 1.17\right)$, which is only possible for ring $\mathrm{D}$ in chair conformation.

Correlations between the signal of $\mathrm{H}-29 \mathrm{a}\left(\delta_{\mathrm{H}} 3.12\right)$ with the signal of $\mathrm{H}-30\left(\delta_{\mathrm{H}} 1.01\right), \mathrm{H}-21\left(\delta_{\mathrm{H}} 1.26\right)$ and $\mathrm{H}-15 \mathrm{ax}$ $\left(\delta_{\mathrm{H}} 2.26\right)$ were also observed. The signal at $\delta_{\mathrm{H}} 3.64(\mathrm{H}-29 \mathrm{~b})$ is correlated with the signals of $\mathrm{H}-27\left(\delta_{\mathrm{H}} 1.17\right)$ and $\mathrm{H}-22$ $\left(\delta_{\mathrm{H}} 1.75\right)$. The NOESY data allowed determining that ring $\mathrm{E}$ also has chair conformation (Figure 3).

Antimicrobial activities have been described for pentacyclic triterpenes, such as oleananes,$^{20}$ ursanes ${ }^{20}$ friedelanes,,$^{21}$ and lupanes. ${ }^{22}$ It is speculated that the mechanism of action of triterpenes is due to a disruption on the microorganism's cellular membrane. ${ }^{20,23}$ For this reason, the hexane extract and triterpenes 3-oxofriedelane (1), 3-oxo-12 $\alpha$-hydroxyfriedelane (3), 3,16-dioxofriedelane (5) and 3-oxo-12 $\alpha, 29$-dihydroxyfriedelane (6) were tested against standard bacteria strains of Escherichia coli, Citrobacter freundii, Bacillus cereus and against the yeast Candida albicans, using disk diffusion test. The hexane extract was moderately active on disk diffusion test as well as in the broth dilution test, presenting a MIC value of $512 \mu \mathrm{g} / \mathrm{mL}$. From the tested triterpenes, 3-oxo-12 $\alpha$ hydroxyfriedelane (3) was active in the macrodilution test, presenting a $\mathrm{MIC}=512 \mu \mathrm{g} / \mathrm{mL}$ against $C$. albicans. The activity of $\mathbf{3}$ was lower in comparison to that was produced by miconazole $(16 \mu \mathrm{g} / \mathrm{mL})$, and was not detected in the disk diffusion test, probably because of low polarity of this compound. ${ }^{24}$

\section{Supplementary Information}

Spectra (IR, 1D/2D NMR and EM) and Tables of antimicrobial test results are available free of charge at http://jbcs.org.br as PDF file.

\section{Acknowledgments}

The authors thank the Fundação de Amparo a Pesquisa do Estado de Minas Gerais (FAPEMIG, Grants CEX APQ-1863-5.02/07 and PRONEX EDT-479/07), for financial support. F. C. S. thanks Conselho Nacional de Desenvolvimento Científico e Tecnológico (CNPq) for scholarship.

\section{References}

1. Schaneberg, B. T.; Green, D. K.; Sneden, A. T.; J. Nat. Prod. 2001, 64, 624.

2. Cordeiro, P. J. M.; Vilegas, J. H. Y.; Lanças, F. M.; J. Braz. Chem. Soc. 1999, 10, 523.

3. Sannomiya, M.; Vilegas, W.; Rastrelli, L.; Pizza, C.; Phytochemistry 1998, 49, 237.

4. Da Silva, M. S.; De Sousa, D. P.; Medeiros, V.M.; Folly, M. A. B.; Tavares, J. F.; Barbosa-Filho, J. M.; Biochem. Syst. Ecol. 2008, 36, 500 .

5. Lindsey, K. L.; Budesinsky, M.; Kohout, L.; Staden, J. V.; S. Afr. J. Bot. 2006, 72, 473.

6. Andrade, S. F.; Comunello, E.; Noldin, V. F.; Monache, F. D.; Filho, V. C.; Niero, R.; Arch. Pharm. Res. 2008, 31,41 . 
7. Orabi, K. Y.; Al-Qasoumi, S. I.; El-Olemy, M.; Mossa, J. S.; Muhammad, I.; Phytochemistry 2001, 58, 475.

8. Oliveira, M. L. G.; Duarte, L. P.; Silva, G. D. F.; Vieira Filho, S. A.; Knupp, V. F.; Alves, F. G. P.; Magn. Reson. Chem. 2007, $45,895$.

9. Wagner, H.; Bladt, S.; Plant Drug Analysis, Springer: Berlin, 1996.

10. Takahashi, J. A.; Castro, M. C. M.; Souza, G. G.; Lucas, E. M. F.; Bracarense, A. A. P.; Abreu, L. M.; Marriel, I. E.; Oliveira, M. S.; Floreano, M. B.; Oliveira, T. S.; J. Med. Mycol. 2008, $18,198$.

11. Lana, E. J. L.; Carazza, F.; Takahashi, J. A.; J. Agric. Food Chem. 2006, 54, 2053.

12. Mahato, S. B.; Kundu, A. P.; Phytochemistry 1994, 37, 1517.

13. Agrawal, P. K.; Jain, D. C.; Prog. NMR Spectrosc. 1992, $24,1$.

14. Salazar, G. D. C.; Silva, G. D. F.; Duarte, L. P.; Vieira Filho, S. A.; Lula, I. S.; Magn. Reson. Chem. 2000, 38, 977.

15. Wandji, J.; Wansi, J. D.; Fuendjiep, V.; Dagne, E.; Mulholland, D. A.; Tillequin, F.; Fomum, Z. T.; Sondengam, B. L.; Nkeh, B. C.; Njamen, D.; Phytochemistry 2000, 54, 811.

16. Patra, A.; Chaudhuri, S. K.; Magn. Reson. Chem. 1987, $25,95$.

17. Matos, F. J. A.; Introdução a Fitoquímica Experimental, UFC: Fortaleza, Brasil, 1998.
18. Rhourri-Frih, B. ; Chaimbault, P. ; Claude, B. ; Lamy, C. ; André, P. ; Lafosse, M. ; J. Mass. Spectrom. 2009, 44, 71.

19. Patra, A.; Chaudhuri, S. K.; Rübgger, H.; J. Indian Chem. Soc. 1990, 67, 394.

20. Saleem, M.; Nazir, M.; Ali, M. S.; Hussain, H.; Lee, Y. S.; Riaz, N.; Jabbar, A.; Nat. Prod. Rep. 2010, 27, 238.

21. Chiozem, D. D.; Trinh-Van-Dufat, H.; Wansi, J. D.; Djama, C. M.; Fannang, V. S.; Seguin, E.; Tillequin, F.; Wandji, J.; Chem. Pharm. Bull. 2009, 57, 1119.

22. Awanchiri, S. S.; Trinh-Van-Dufat, H.; Shirri, J. C.; Dongfack, M. D. J.; Nguenang, G. M.; Boutefnouchet, S.; Fomum, Z. T.; Seguin, E.; Verite, P.; Tillequin, F.; Wandji, J.; Phytochemistry 2009, 70, 419.

23. Zellner, B. D.; Amorim, A. C. L.; Miranda, A. L. P.; Alves, R. J. V.; Barbosa, J. P.; Costa, G. L.; Rezende, C. M.; J. Braz. Chem. Soc. 2009, 20, 322.

24. Araújo, F. M.; Passos, M. G. V. M.; Lima, E. O.; Roque, N. F.; Guedes, M. L. S.; Souza-Neta, L. C.; Cruz, F. G.; Martins, D.; J. Braz. Chem. Soc. 2009, 20, 1805.

Submitted: December 22, 2009 Published online: February 8, 2011 


\title{
Chemical Constituents from Branches of Maytenus gonoclada (Celastraceae) and Evaluation of Antimicrobial Activity
}

\author{
Fernando C. Silva ${ }^{a, c}$ Lucienir P. Duarte, ${ }^{*, a}$ Grácia D. F. Silva, ${ }^{a}$ Sidney A. V. Filho, ${ }^{a, b}$ \\ Ivana S. Lula, ${ }^{a}$ Jacqueline A. Takahashic and William S. T. Sallum ${ }^{c}$ \\ ${ }^{a}$ Núcleo de Estudos de Plantas Medicinais and ${ }^{c}$ Laboratório de Biotecnologia e Bioensaios, \\ Departamento de Química, Universidade Federal de Minas Gerais, \\ Av. Antônio Carlos, 6627, Pampulha, 31270-901 Belo Horizonte-MG, Brazil \\ ${ }^{b}$ Escola de Farmácia, Universidade Federal de Ouro Preto, Rua Costa Sena, 171, \\ 35400-000 Ouro Preto-MG, Brazil
}

Table S1. Antimicrobial activities of hexane extract and compounds 1, 3, 5 and $\mathbf{6}$ (each concentration at $100 \mu \mathrm{g} / \mathrm{mL}$ )

\begin{tabular}{lcccc}
\hline Samples & \multicolumn{2}{c}{ Inhibition zone diameter (mm) } \\
\cline { 2 - 5 } & E. coli & C. freundii & B. cereus & C. albicans \\
\hline Hexane extract & ND & ND & ND & 8 \\
Compound $\mathbf{1}$ & ND & ND & ND & ND \\
Compound 3 & ND & ND & ND & ND \\
Compound $\mathbf{5}$ & ND & ND & ND & ND \\
Compound 6 & ND & ND & ND & ND \\
Chloroform $^{\mathrm{a}}$ & ND & ND & ND \\
Cloranfenicol $^{\mathrm{b}}$ & 22 & 29 & 20 & - \\
Miconazole $^{\mathrm{c}}$ & - & - & - & 17 \\
\hline
\end{tabular}

${ }^{\mathrm{a} N e g a t i v e ~ c o n t r o l ; ~}{ }^{\mathrm{b} P o s i t i v e ~ c o n t r o l ~(b a c t e r i a) ; ~ ' P o s i t i v e ~ c o n t r o l ~(f u n g u s) ; ~ N D ~(N o t ~ D e t e c t e d) . ~}$

Table S2. Antimicrobial activities of hexane extract and compounds 3

\begin{tabular}{lcccc}
\hline Samples & \multicolumn{4}{c}{ Minimum Inhibitory Concentration $(\mu \mathrm{g} / \mathrm{mL})$} \\
\cline { 2 - 5 } & E. coli & C. freundii & B. cereus & C. albicans \\
\hline Hexane extract & ND & ND & ND & 512 \\
Compound 3 & ND & ND & ND & ND \\
DMSO $^{\text {a }}$ & ND & ND & 8 & - \\
Cloranfenicol $^{b}$ & 8 & 4 & - & 16 \\
Miconazole $^{c}$ & - & - & \\
\hline
\end{tabular}

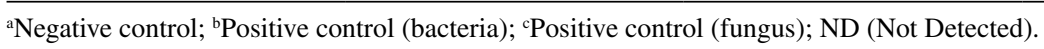

*e-mail: lucienir@ufmg.br 


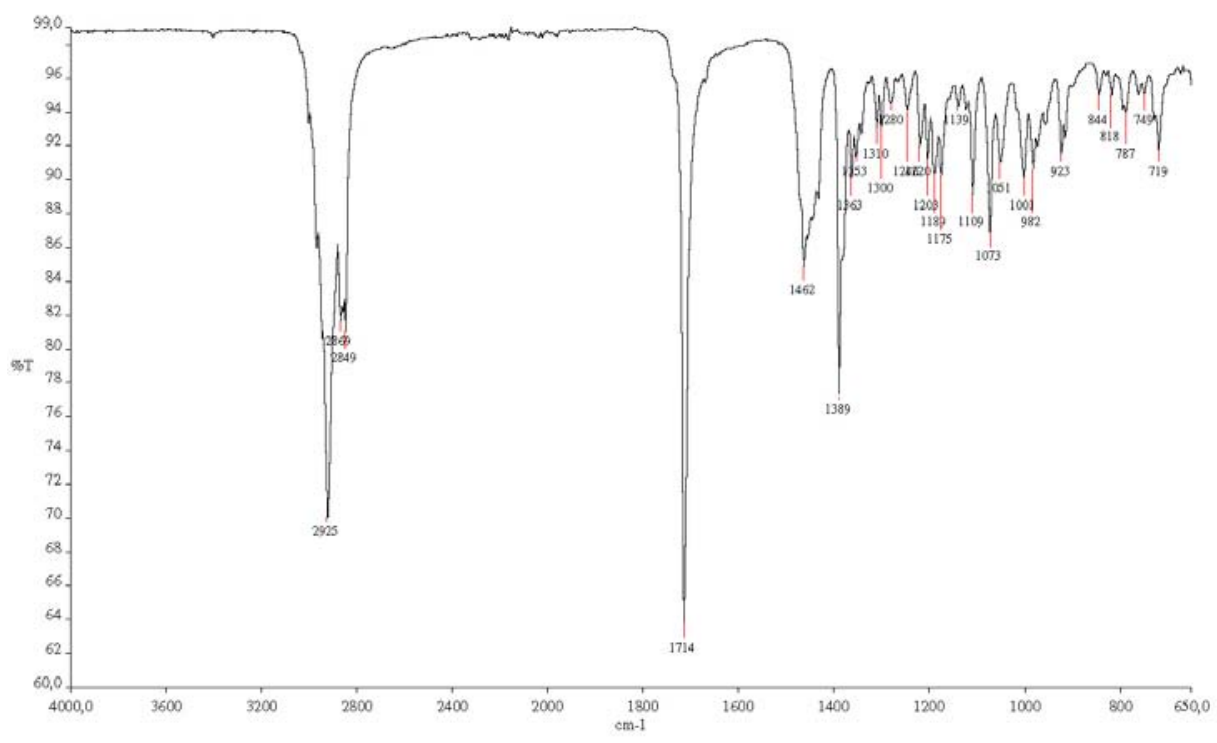

Figure S1. IR spectrum of compound 1 (ATR).

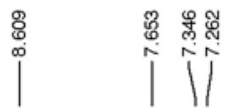

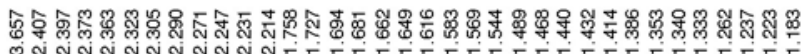
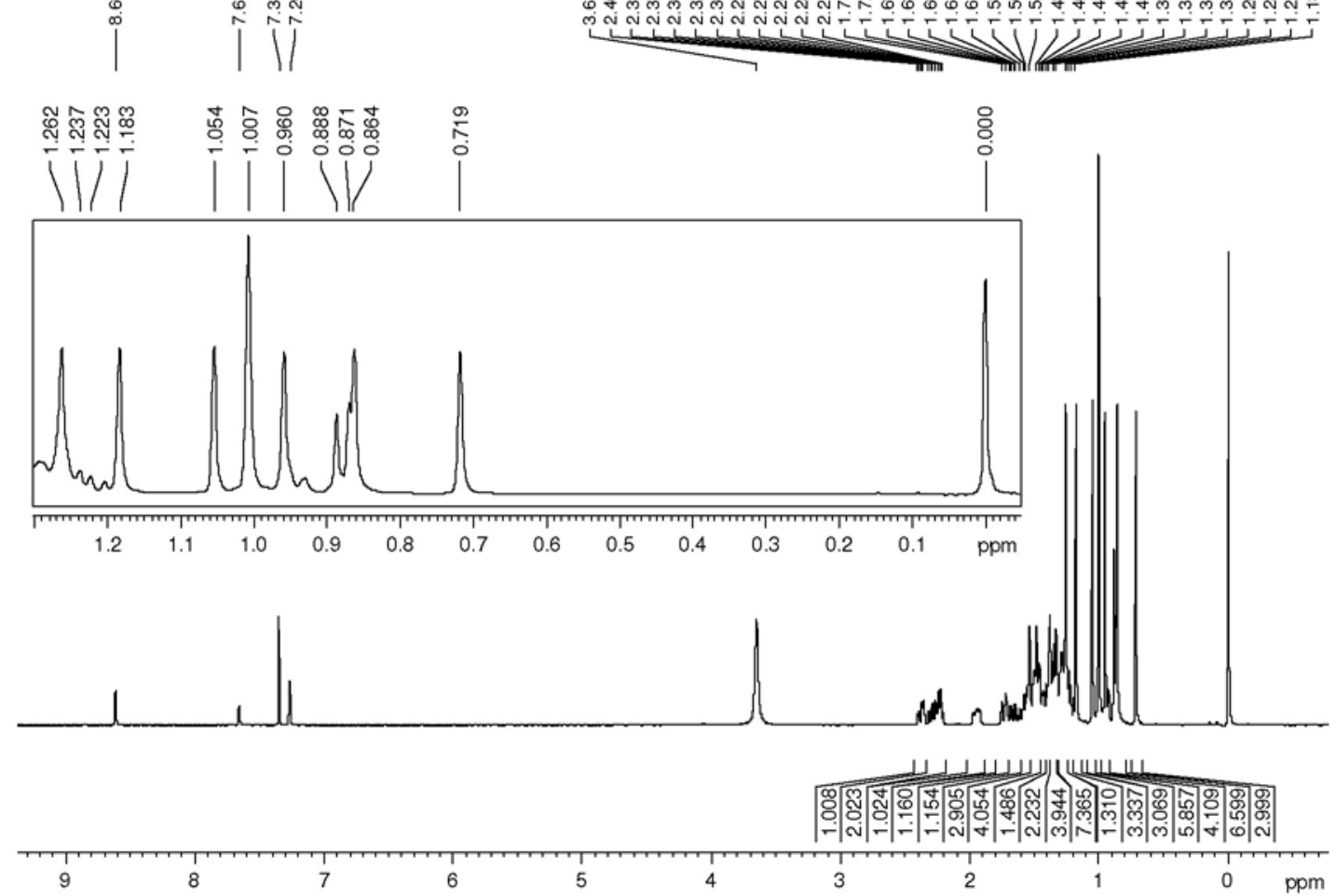

Figure S2. ${ }^{1} \mathrm{H}$ NMR spectrum of compound $\mathbf{1}\left(\mathrm{CDCl}_{3}+\right.$ pyridine- $\left.d_{5}, 400 \mathrm{MHz}\right)$. 


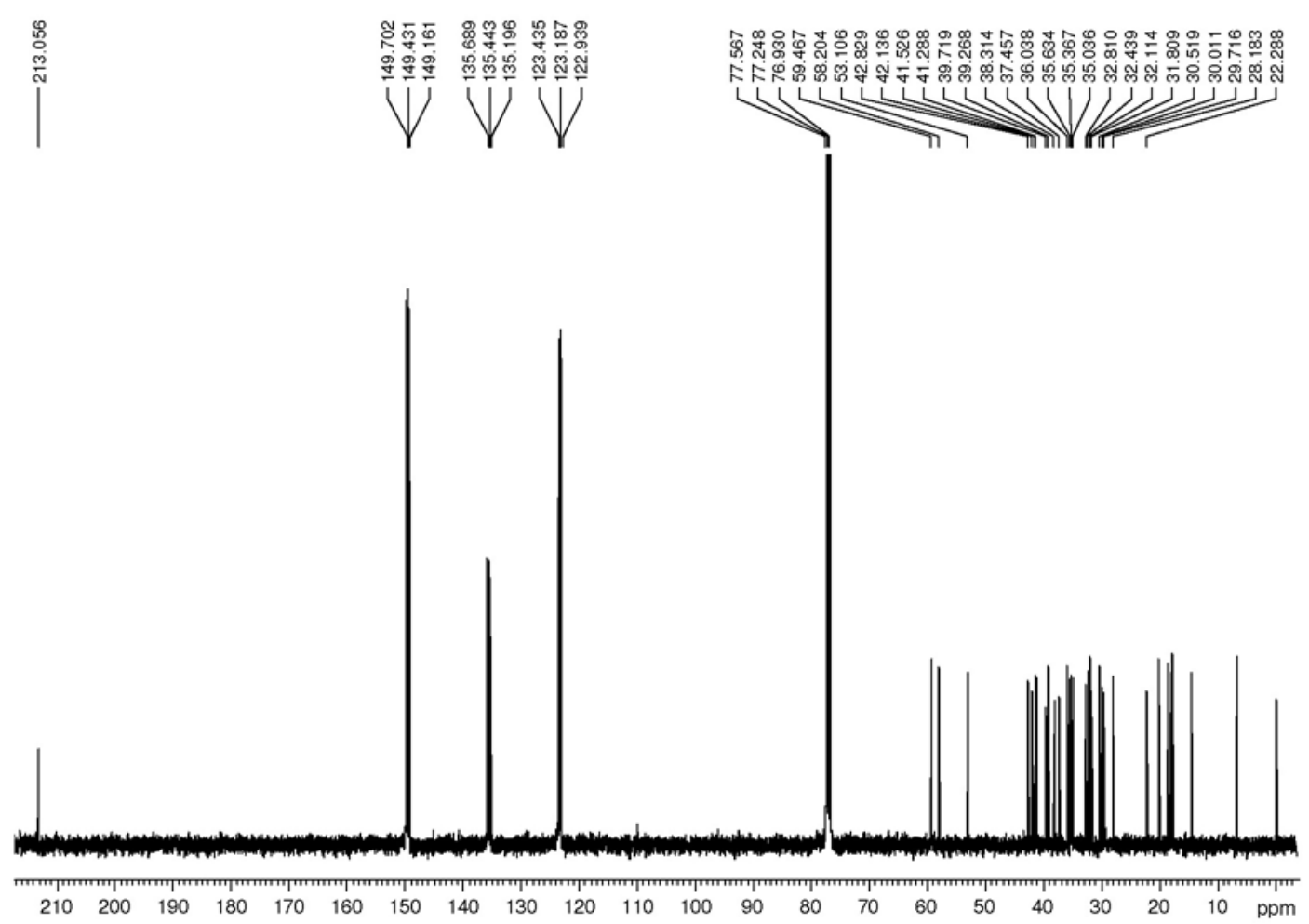

Figure S3. ${ }^{13} \mathrm{C}$ NMR spectrum of compound $\mathbf{1}\left(\mathrm{CDCl}_{3}+\right.$ pyridine- $\left.d_{5}, 100 \mathrm{MHz}\right)$.
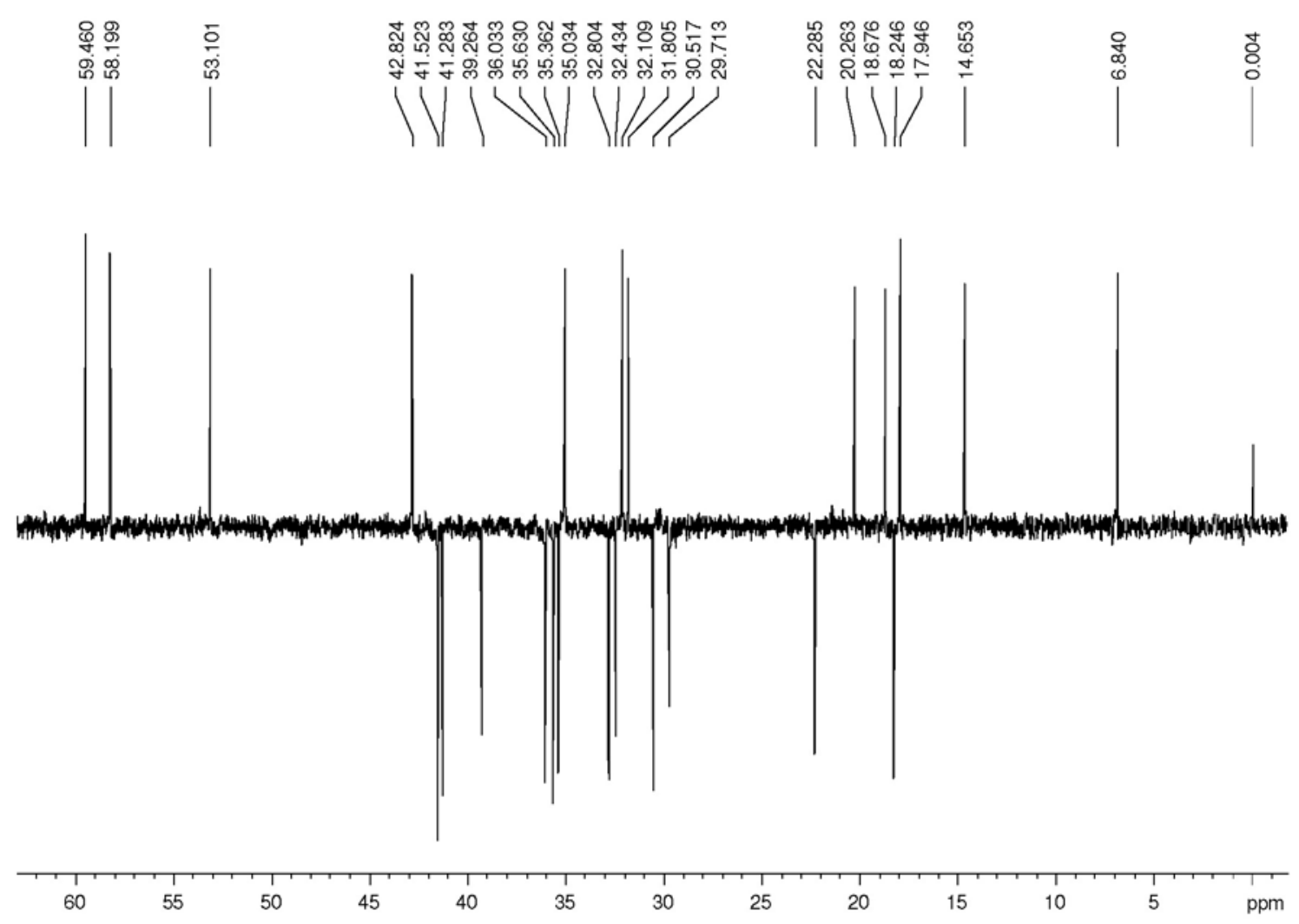

Figure S4. ${ }^{13} \mathrm{C}$ NMR-DEPT spectrum of compound $\mathbf{1}\left(\mathrm{CDCl}_{3}+\right.$ pyridine- $\left.d_{5}, 100 \mathrm{MHz}\right)$. 


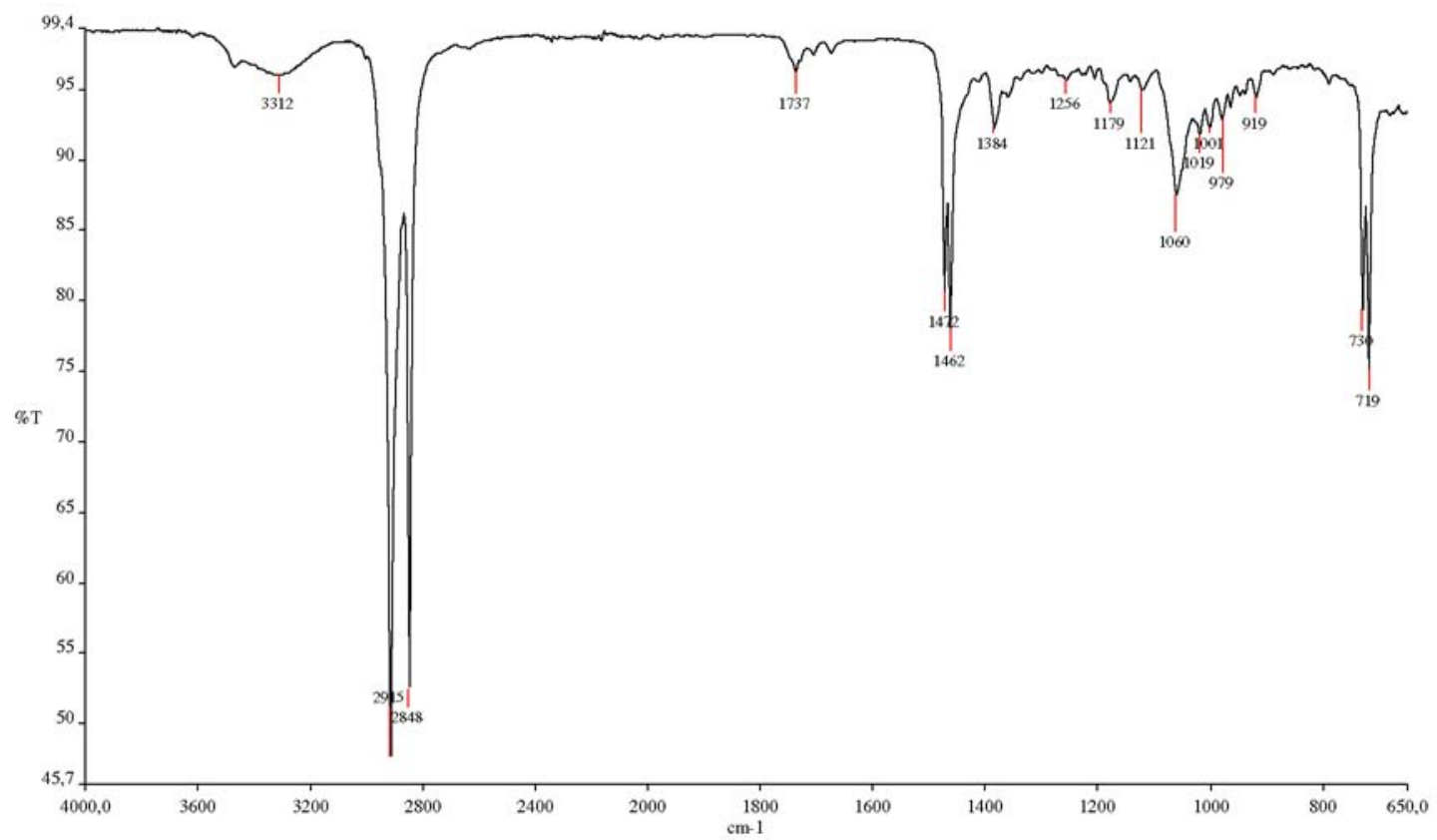

Figure S5. IR spectrum of compound 2 (ATR).

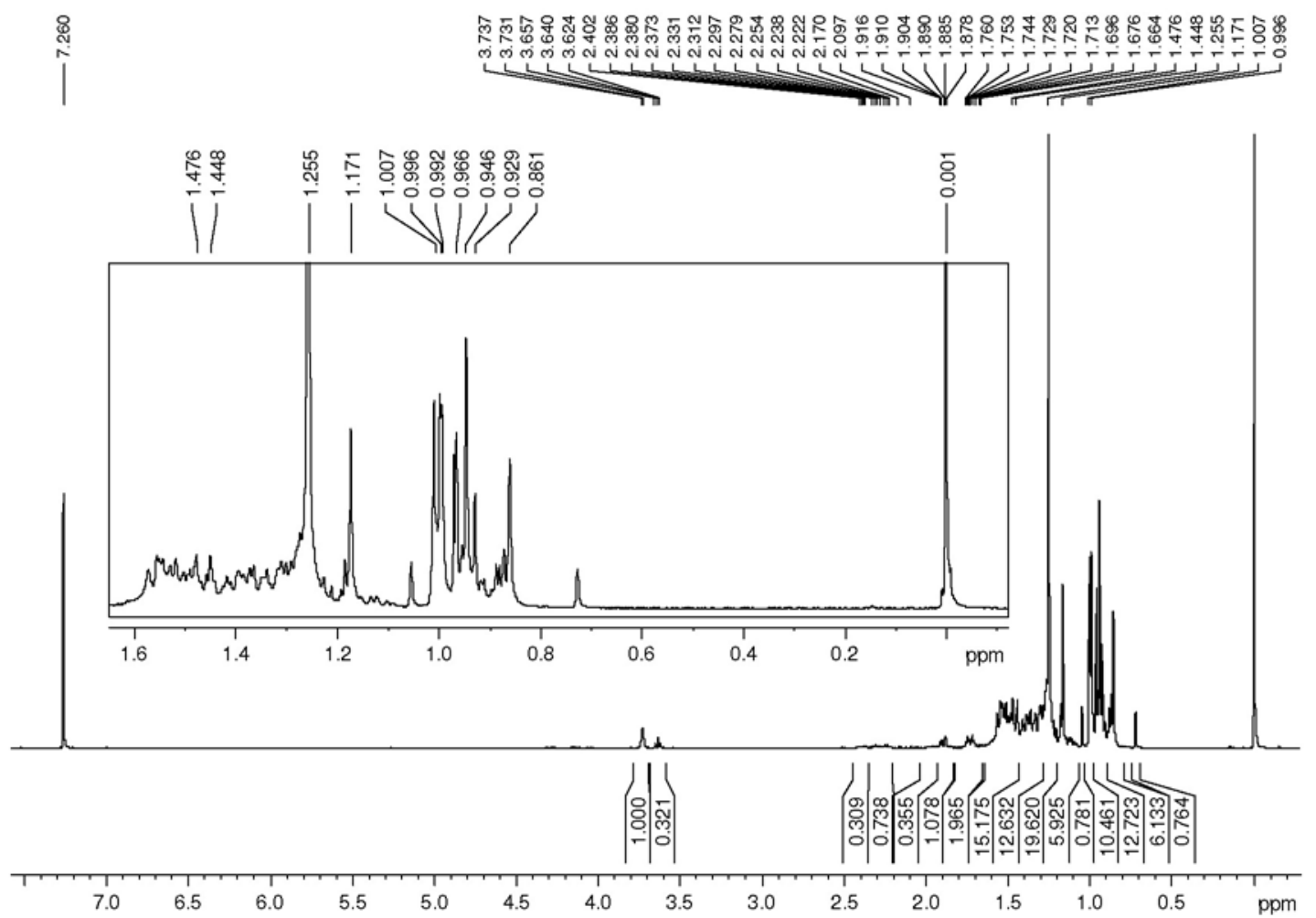

Figure S6. ${ }^{1} \mathrm{H}$ NMR spectrum of compound $2\left(\mathrm{CDCl}_{3}, 400 \mathrm{MHz}\right)$. 


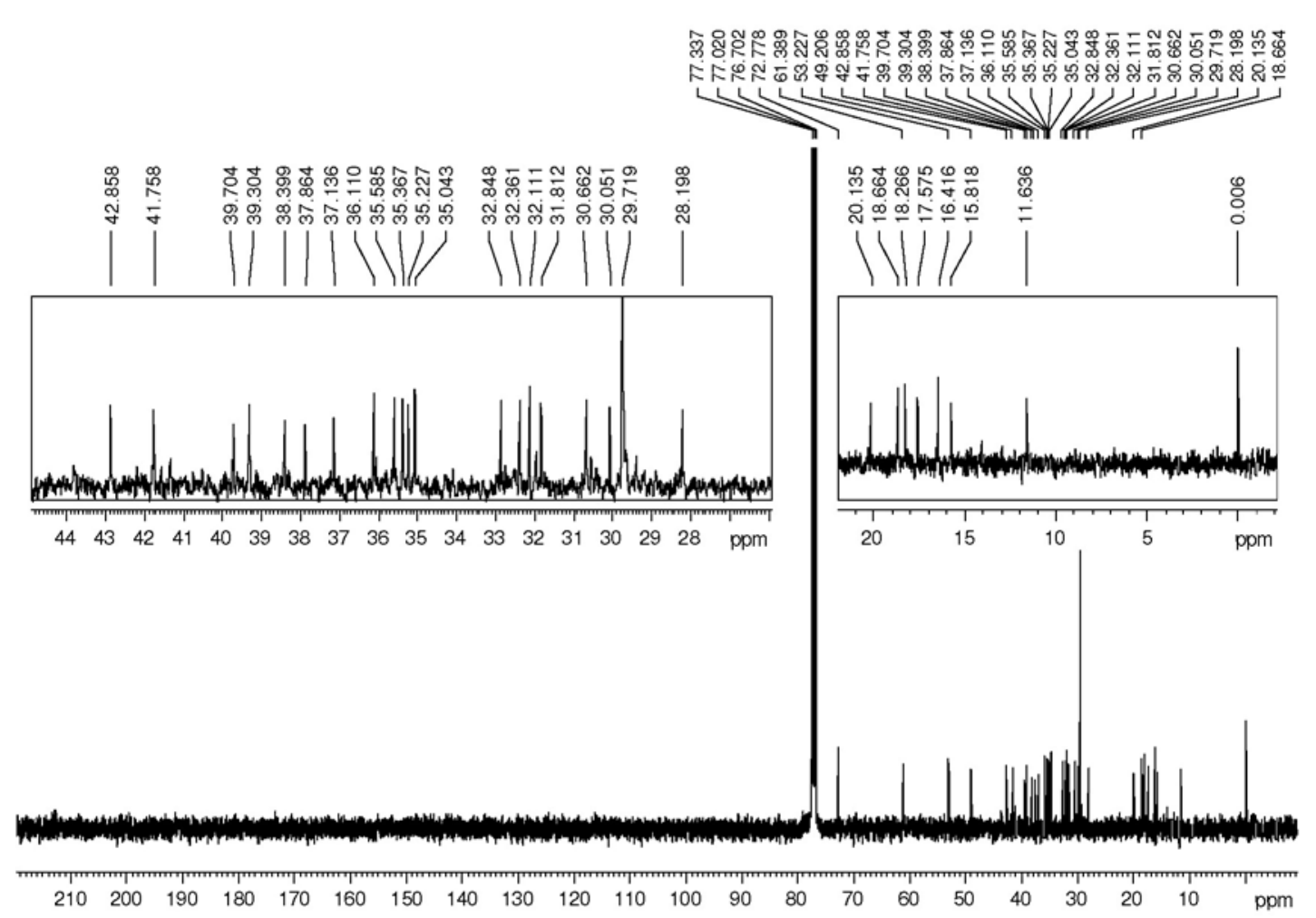

Figure S7. ${ }^{13} \mathrm{C}$ NMR spectrum of compound $2\left(\mathrm{CDCl}_{3}, 100 \mathrm{MHz}\right)$.
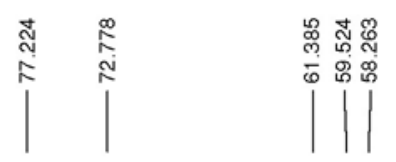

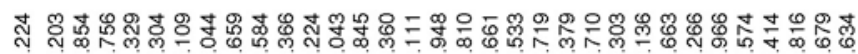

๓
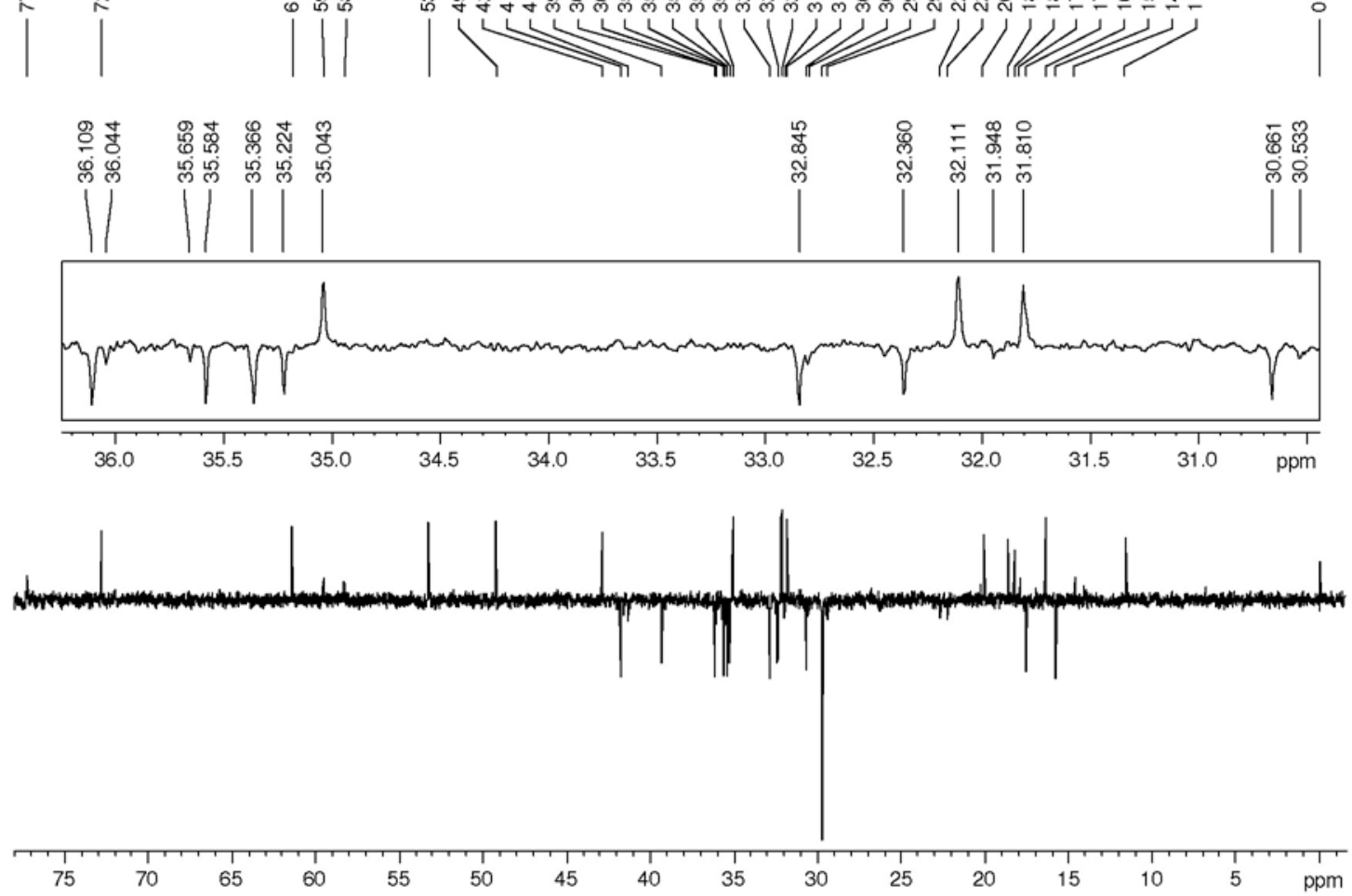

Figure S8. ${ }^{13} \mathrm{C}$ NMR-DEPT spectrum of compound $2\left(\mathrm{CDCl}_{3}, 100 \mathrm{MHz}\right)$. 


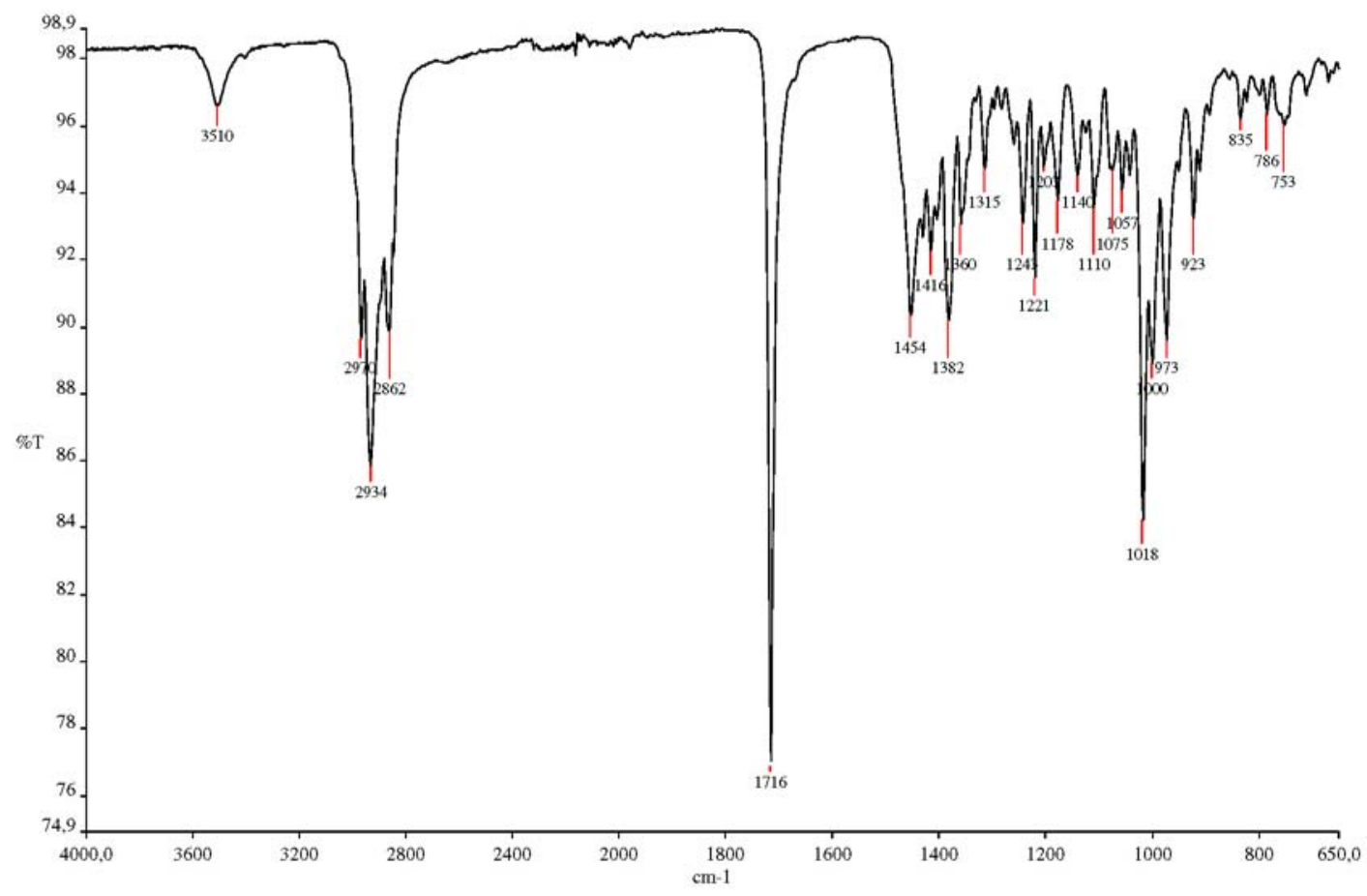

Figure S9. IR spectrum of compound 3 (ATR).

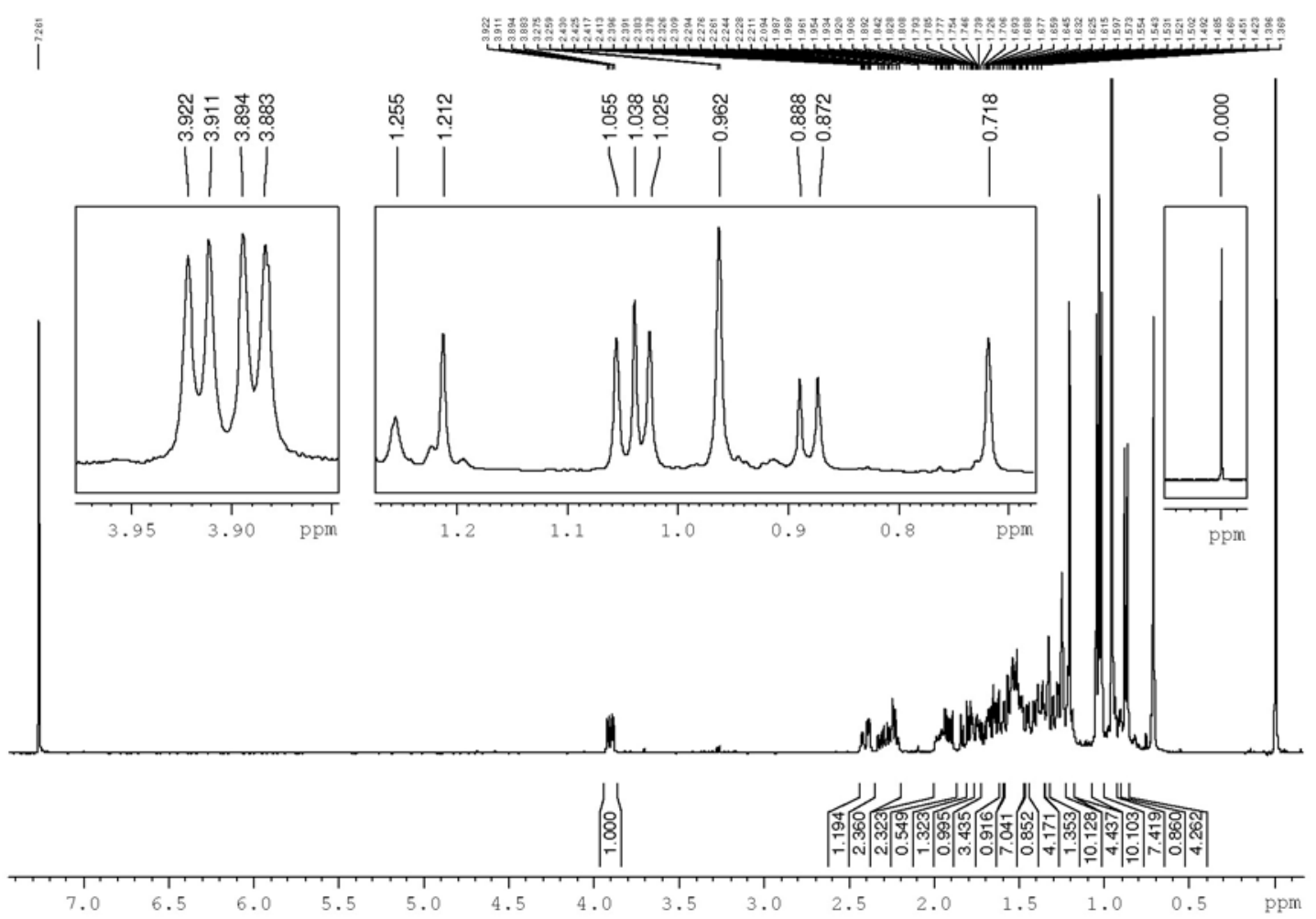

Figure S10. ${ }^{1} \mathrm{H}$ NMR spectrum of compound $\mathbf{3}\left(\mathrm{CDCl}_{3}, 400 \mathrm{MHz}\right)$. 


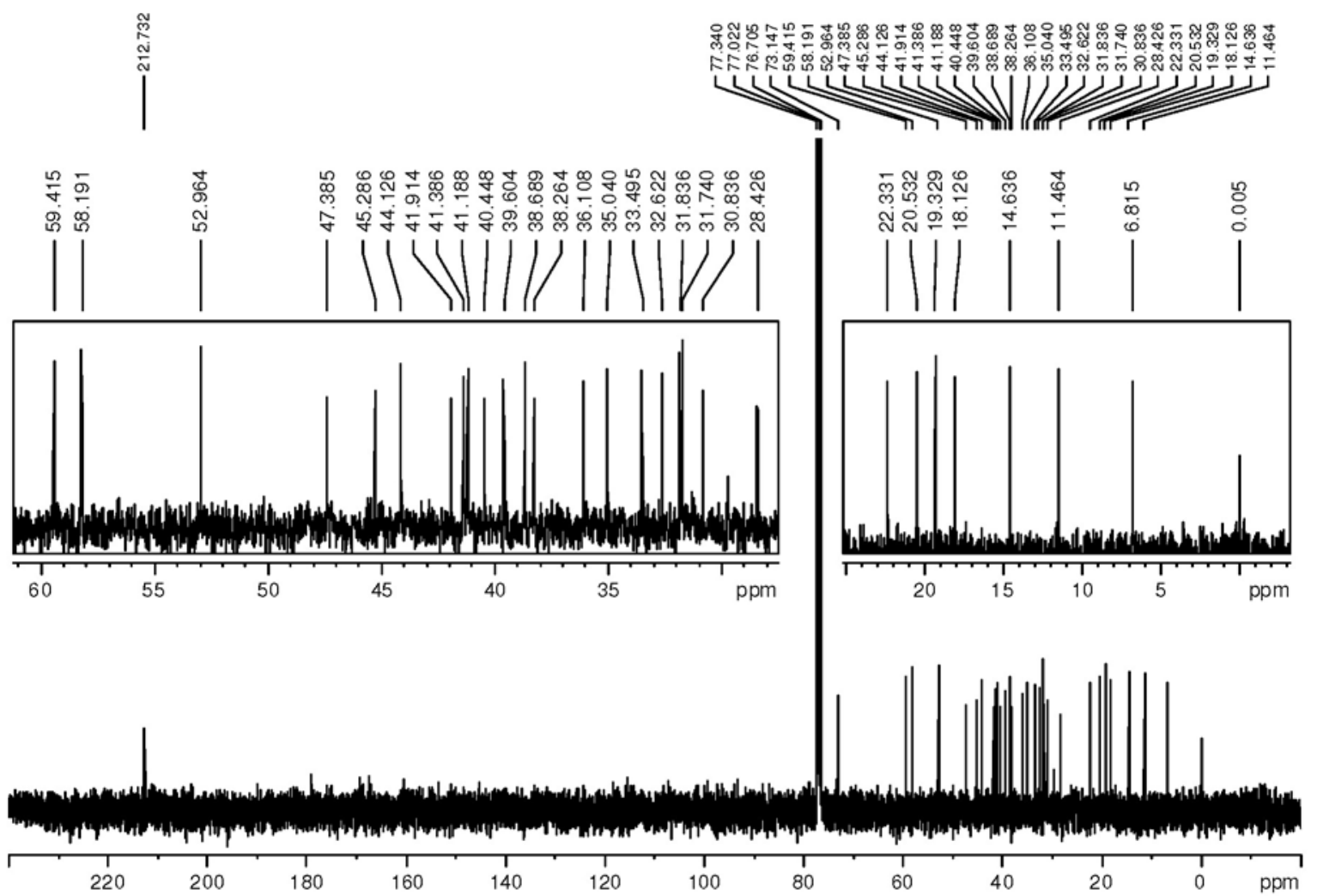

Figure S11. ${ }^{13} \mathrm{C}$ NMR spectrum of compound $\mathbf{3}\left(\mathrm{CDCl}_{3}, 100 \mathrm{MHz}\right)$.
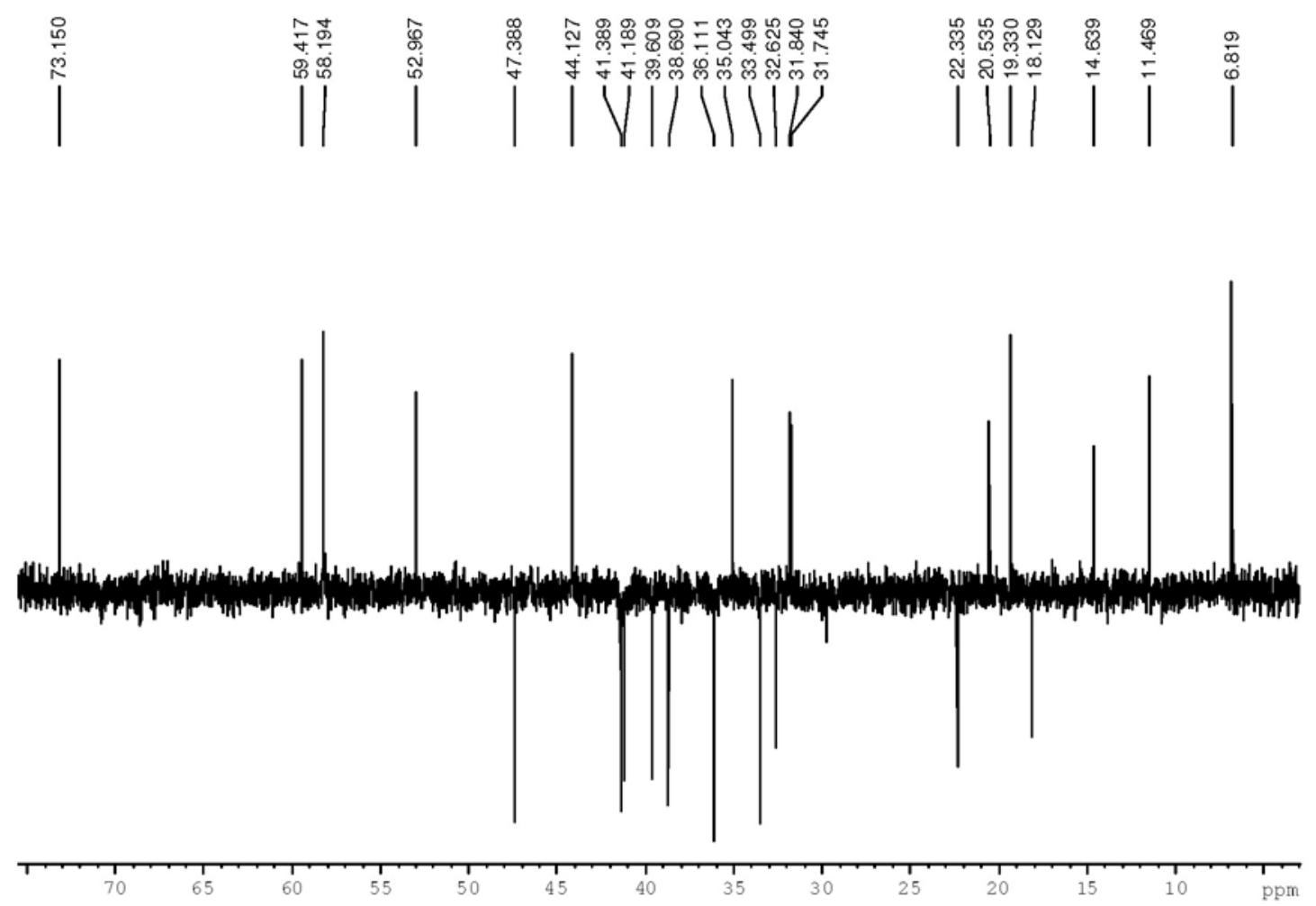

Figure S12. ${ }^{13} \mathrm{C}$ NMR-DEPT spectrum of compound $\mathbf{3}\left(\mathrm{CDCl}_{3}, 100 \mathrm{MHz}\right)$. 


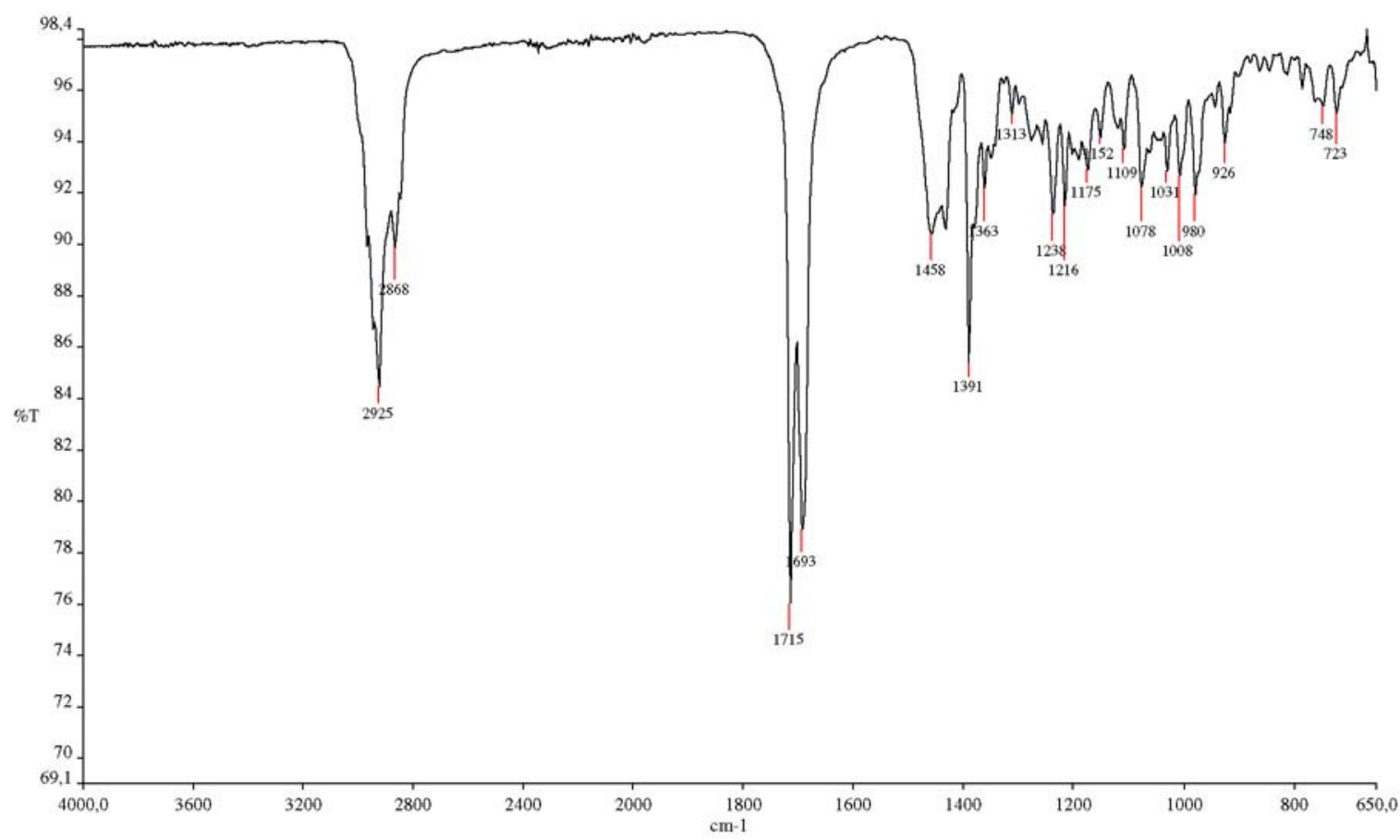

Figure S13. IR spectrum of compound 4 and 5 (ATR).
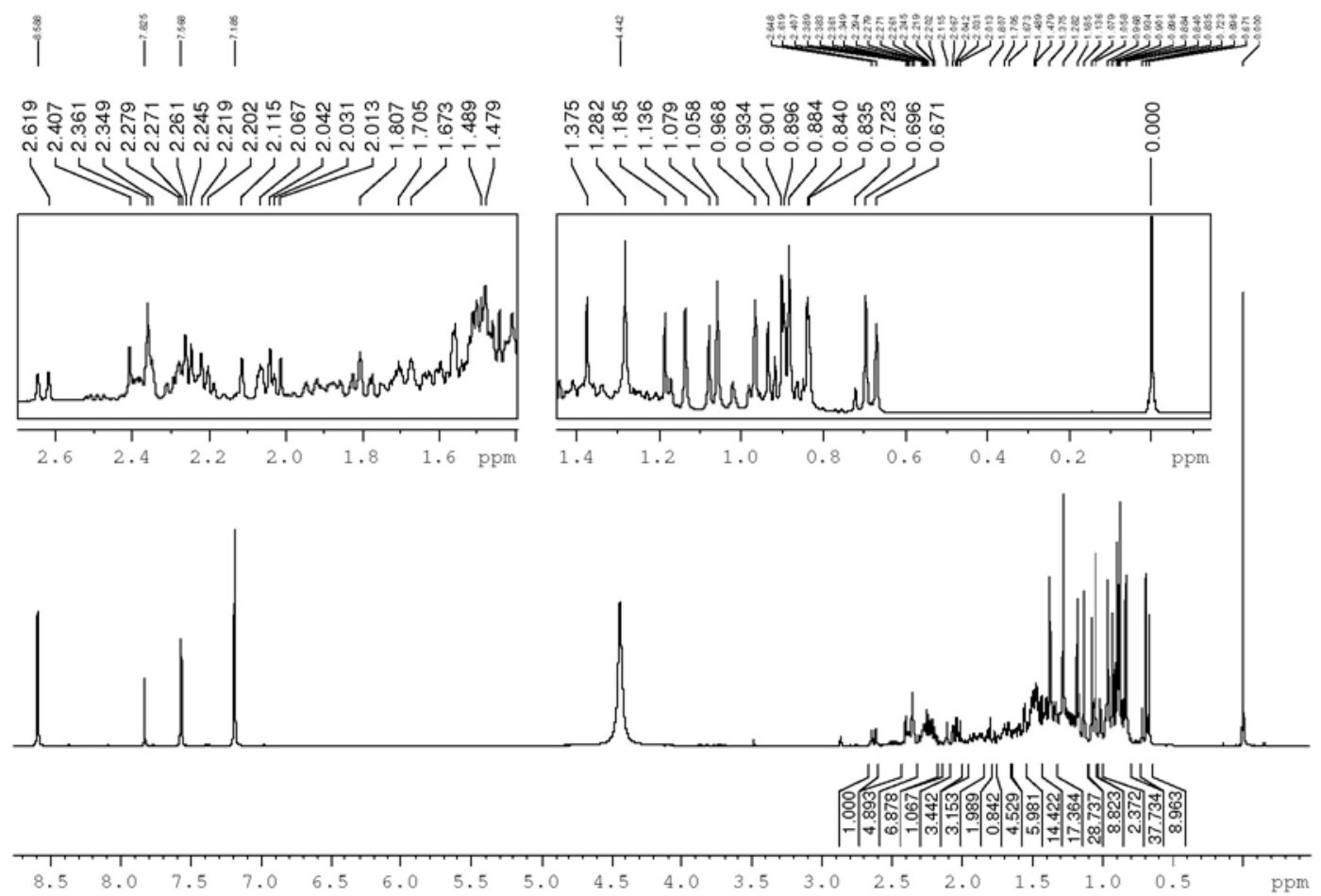

Figure S14. ${ }^{1} \mathrm{H}$ NMR spectrum of compound 4 and $5\left(\mathrm{CDCl}_{3}+\right.$ pyridine- $\left.d_{5}, 400 \mathrm{MHz}\right)$. 


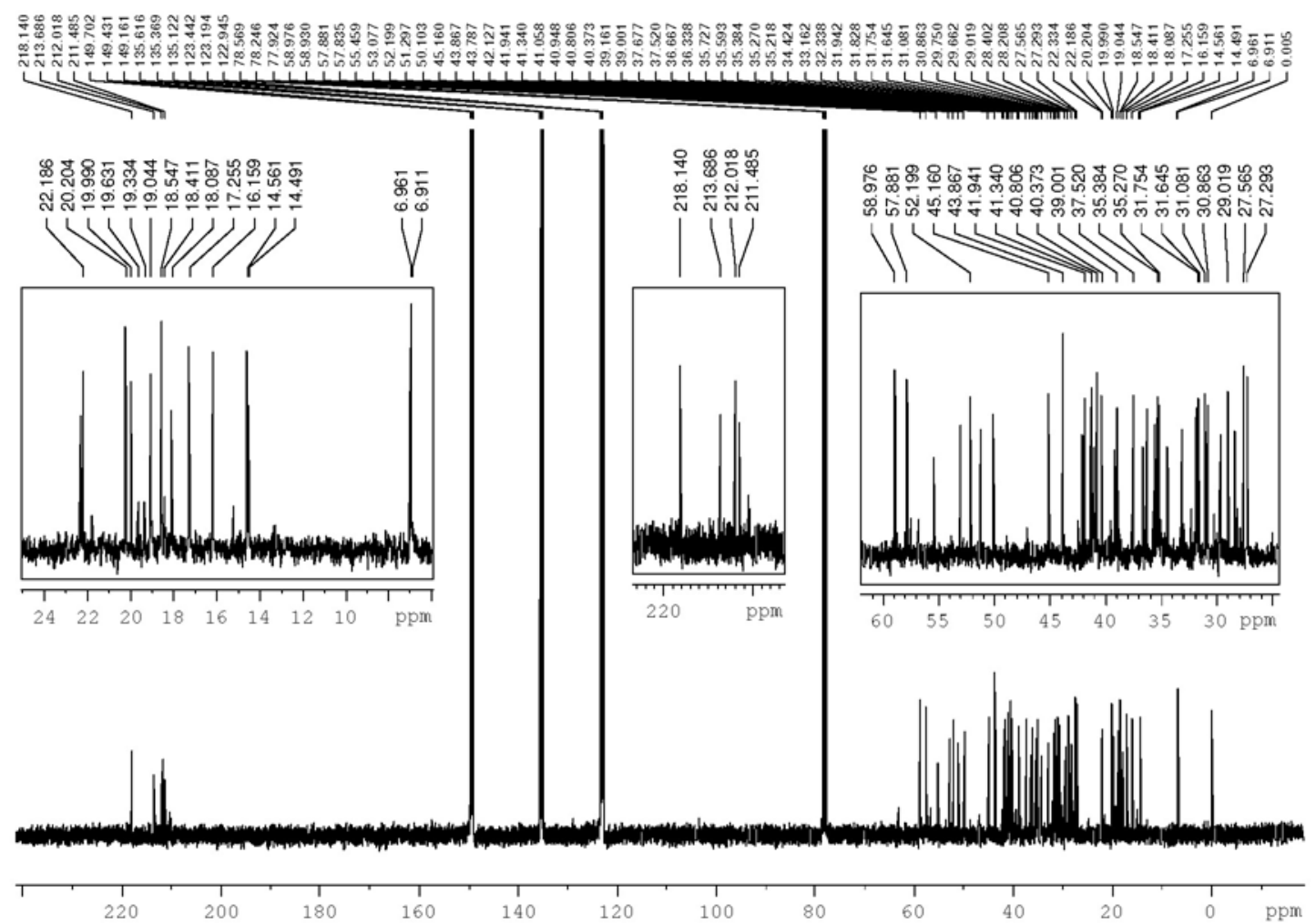

Figure S15. ${ }^{13} \mathrm{C}$ NMR spectrum of compound 4 and $5\left(\mathrm{CDCl}_{3}+\right.$ pyridine- $\left.d_{5}, 100 \mathrm{MHz}\right)$.

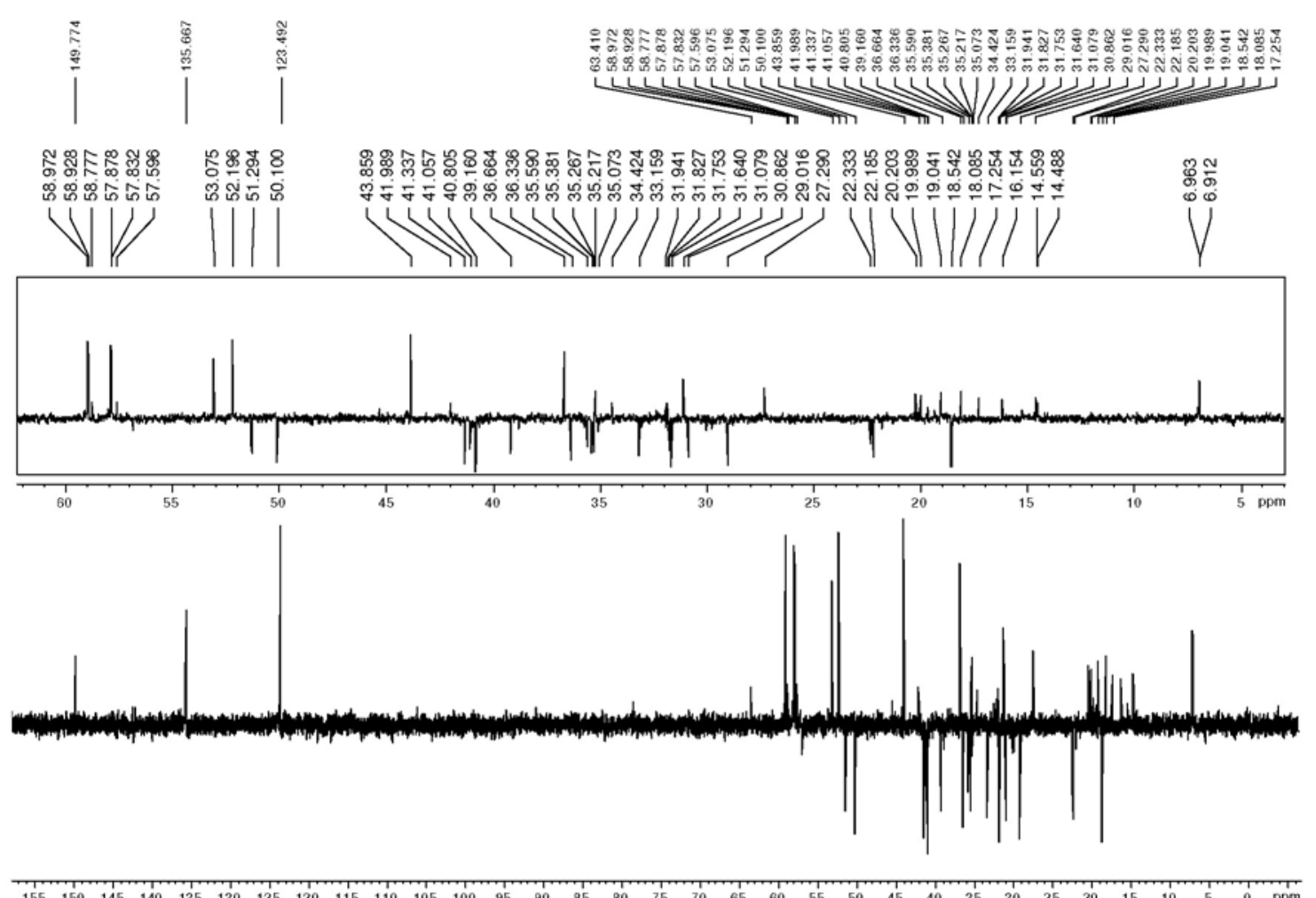

Figure S16. ${ }^{13} \mathrm{C}$ NMR-DEPT spectrum of compound 4 and $5\left(\mathrm{CDCl}_{3}+\right.$ pyridine- $\left.d_{5}, 100 \mathrm{MHz}\right)$. 


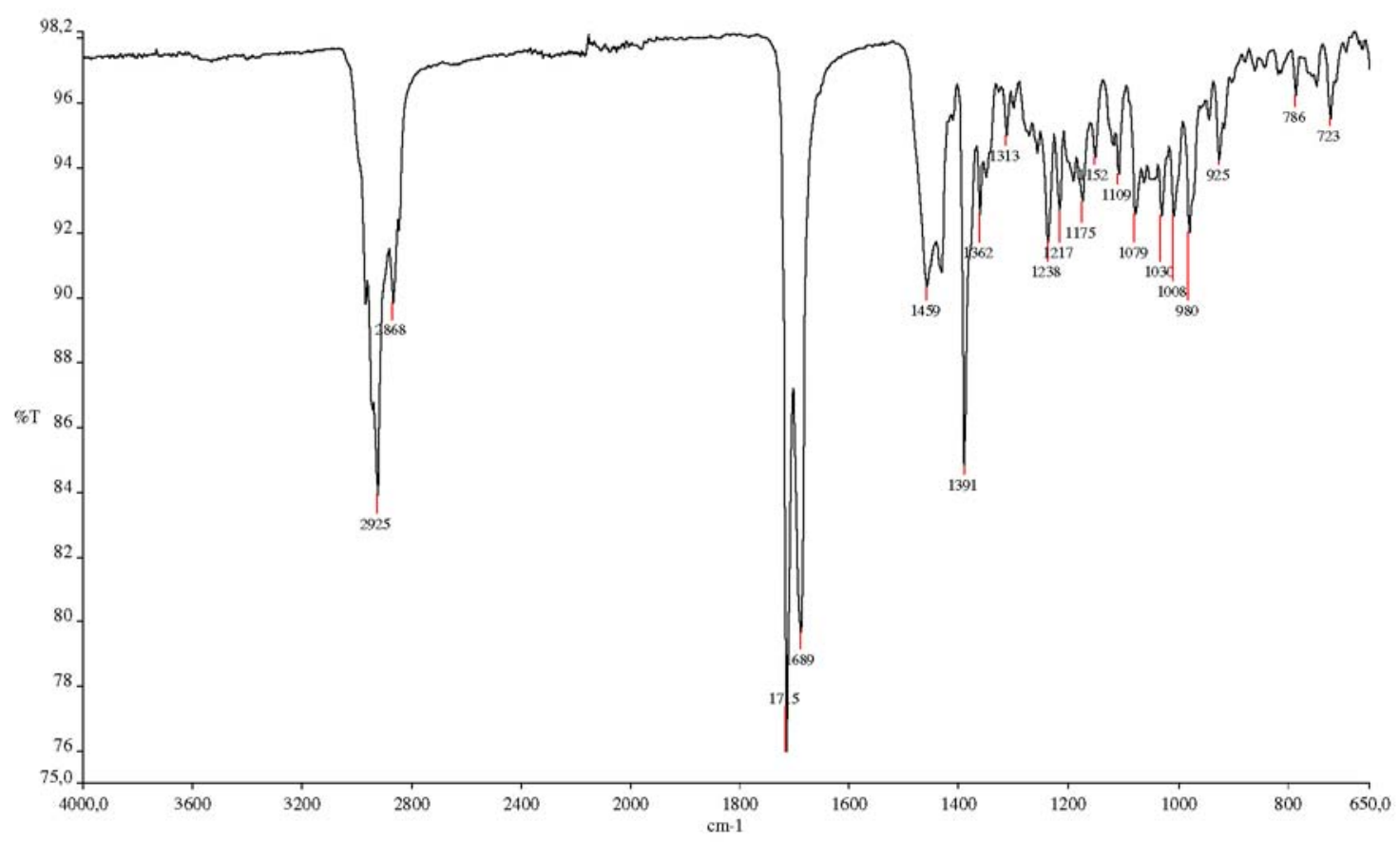

Figure S17. IR spectrum of compound 5 (ATR).

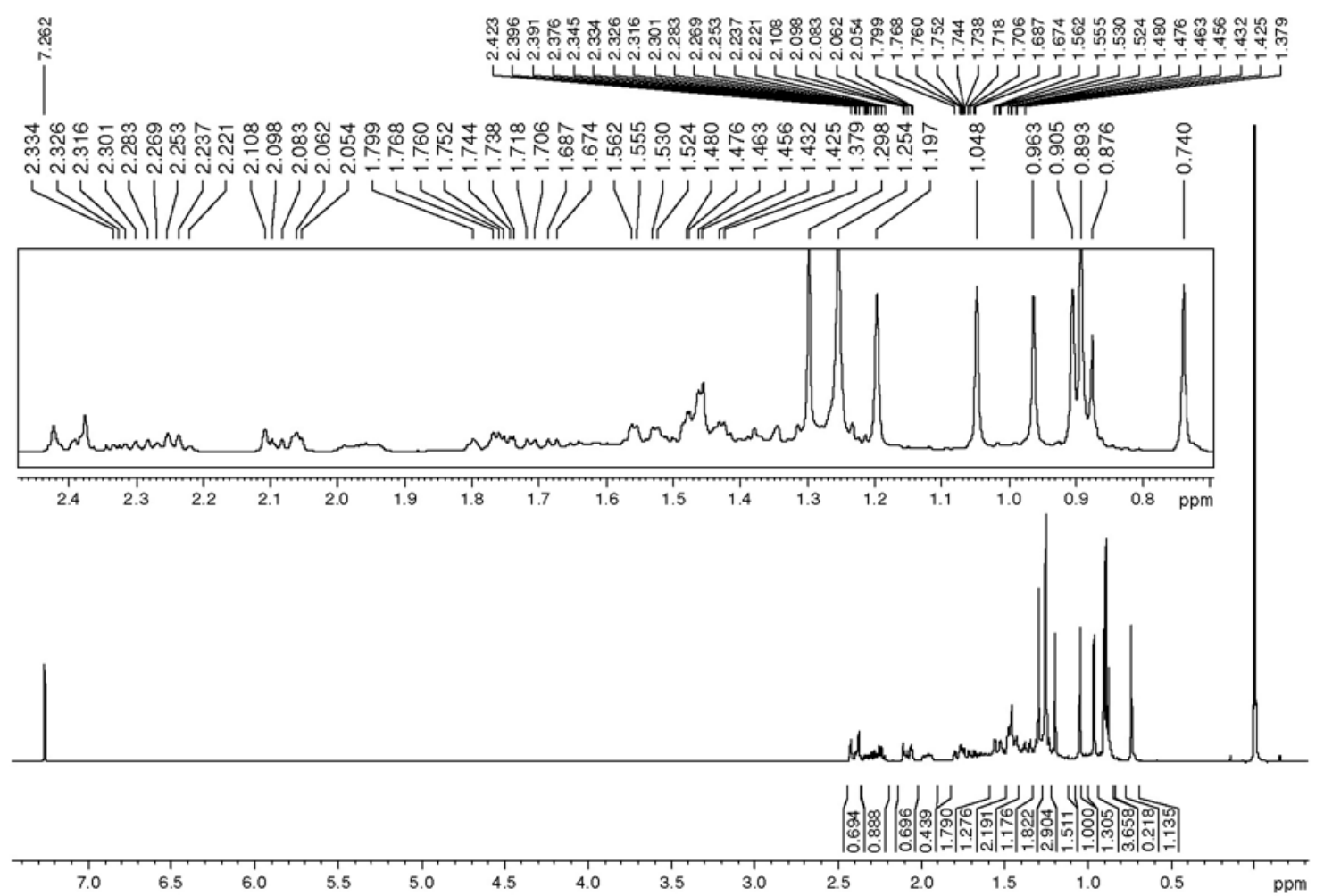

Figure S18. ${ }^{1} \mathrm{H}$ NMR spectrum of compound $\mathbf{5}\left(\mathrm{CDCl}_{3}, 400 \mathrm{MHz}\right)$. 


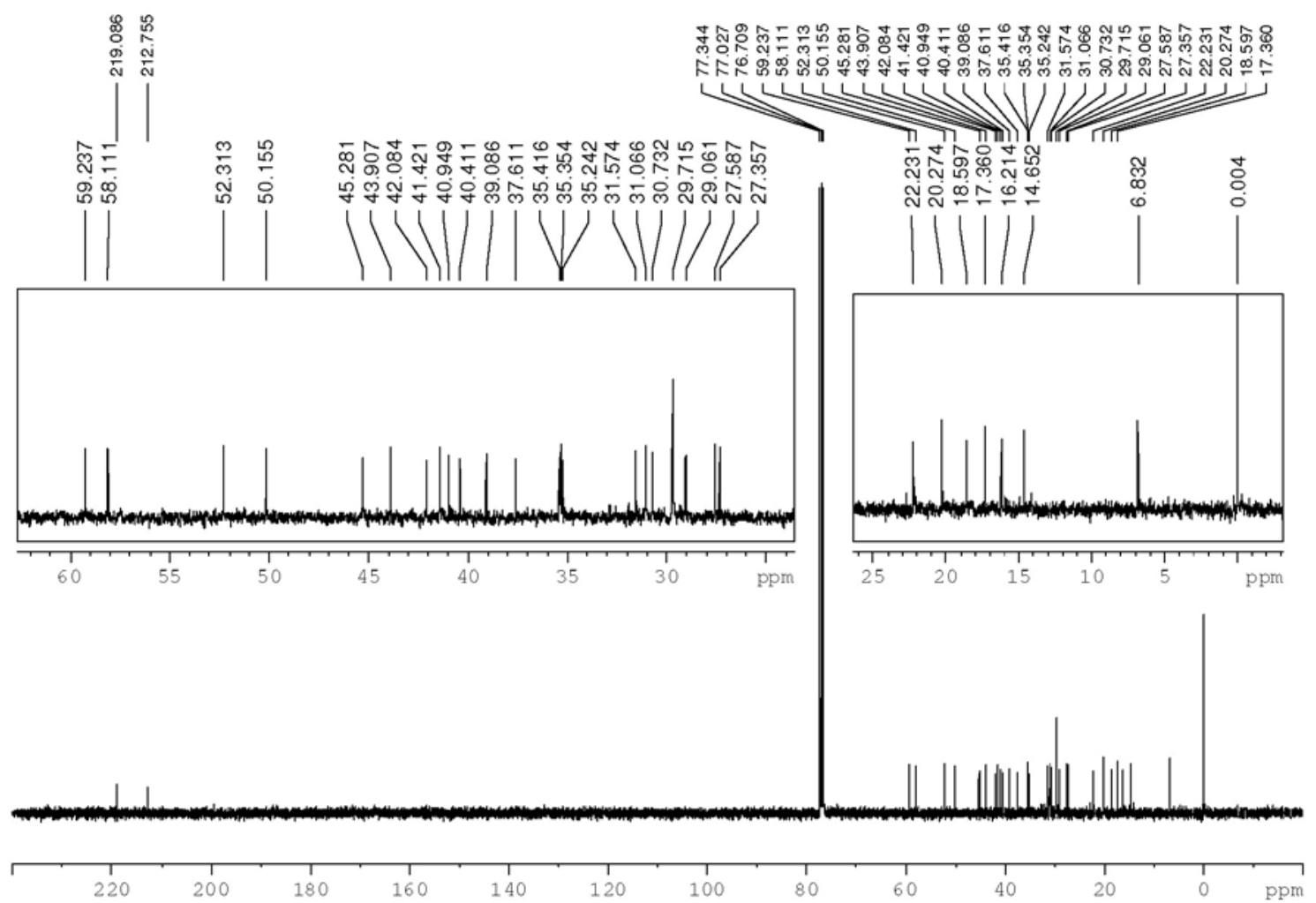

Figure S19. ${ }^{13} \mathrm{C}$ NMR spectrum of compound $\mathbf{5}\left(\mathrm{CDCl}_{3}, 100 \mathrm{MHz}\right)$.
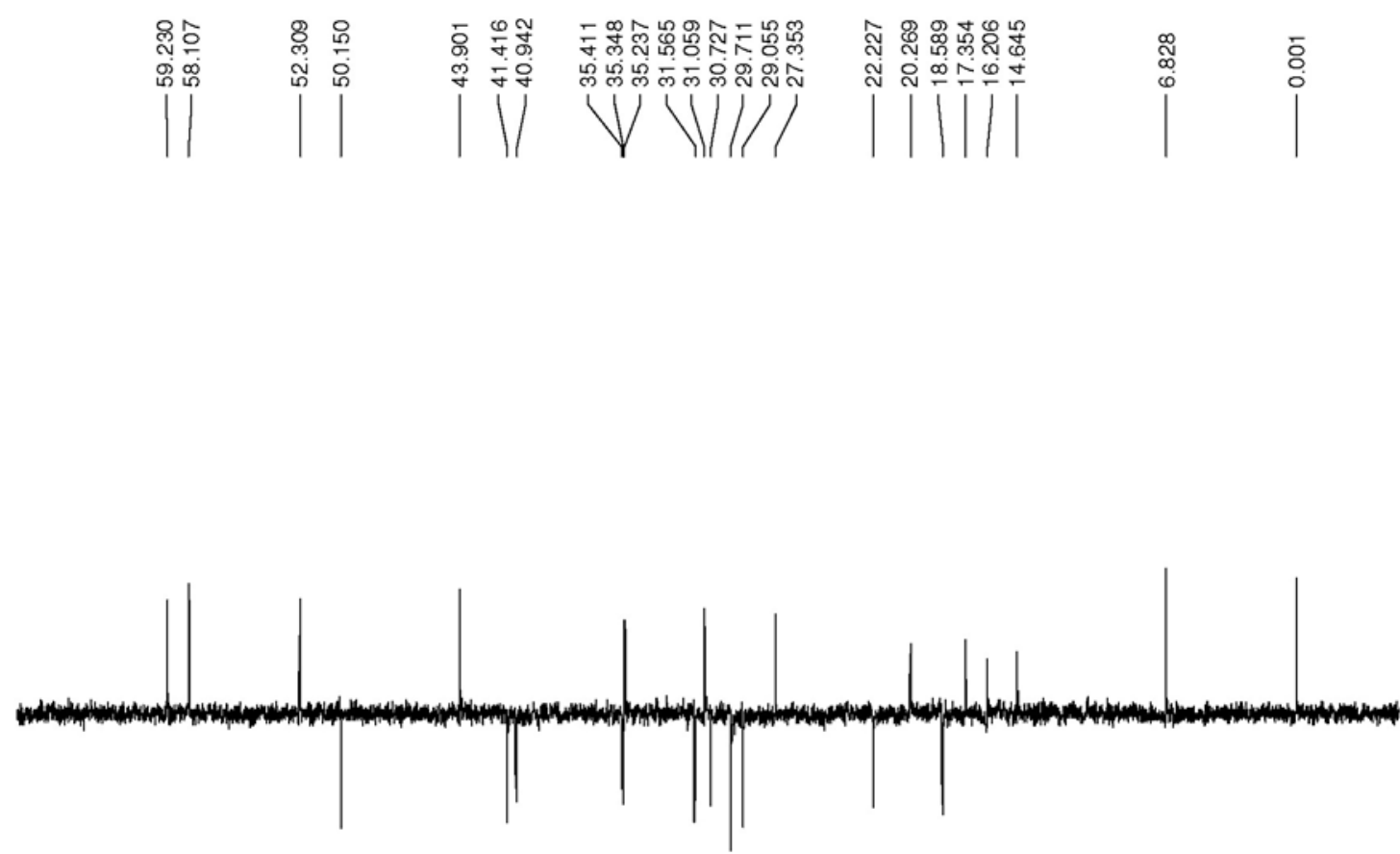

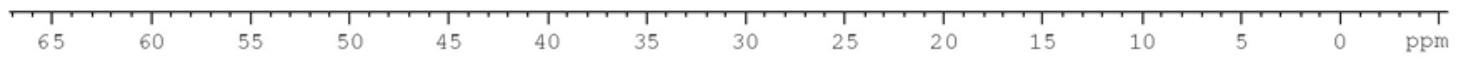

Figure S20. ${ }^{13} \mathrm{C}$ NMR-DEPT spectrum of compound $5\left(\mathrm{CDCl}_{3}, 100 \mathrm{MHz}\right)$. 


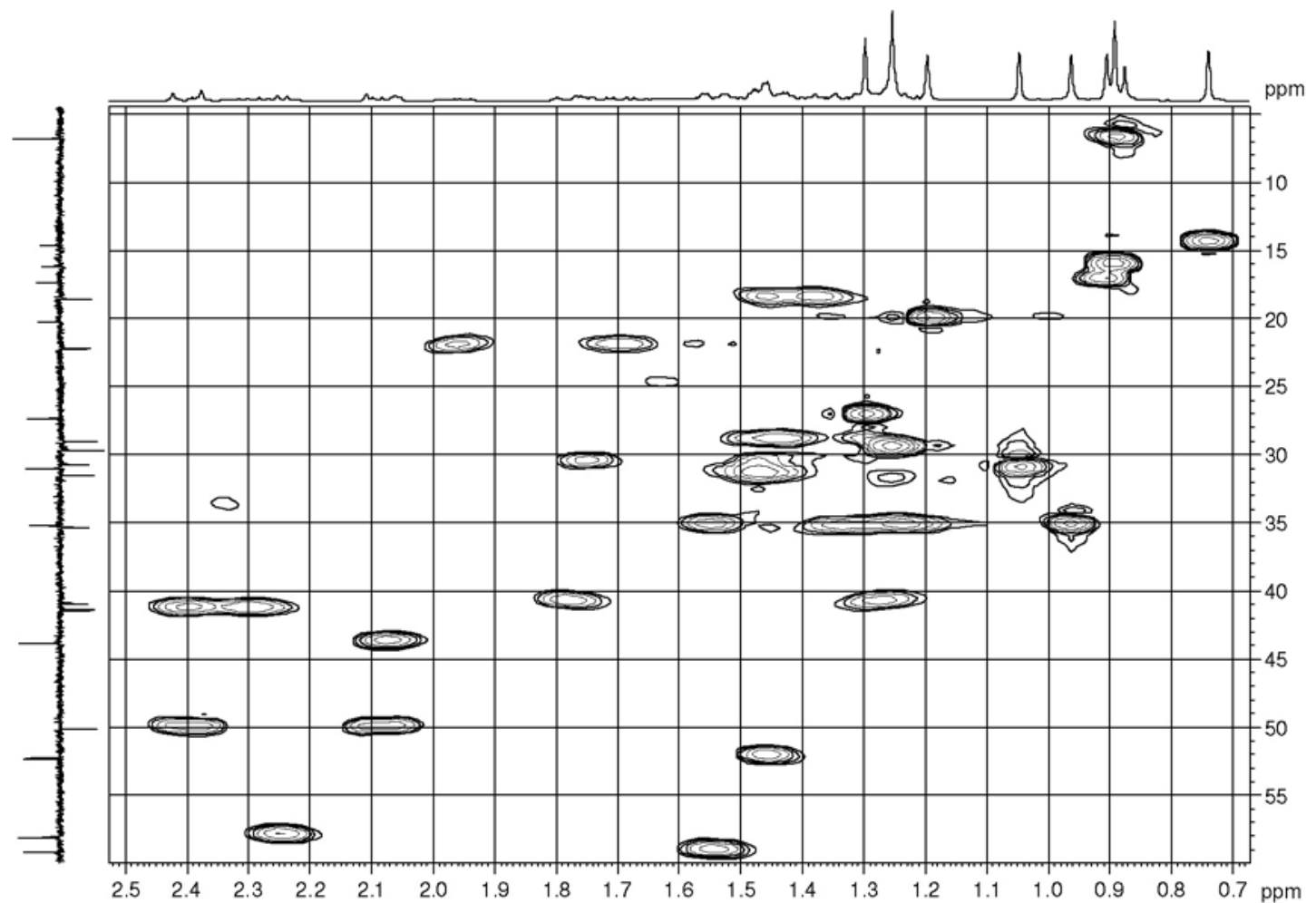

Figure S21. HSQC spectrum of compound $5\left(\mathrm{CDCl}_{3}, 400 \mathrm{MHz}\right)$.

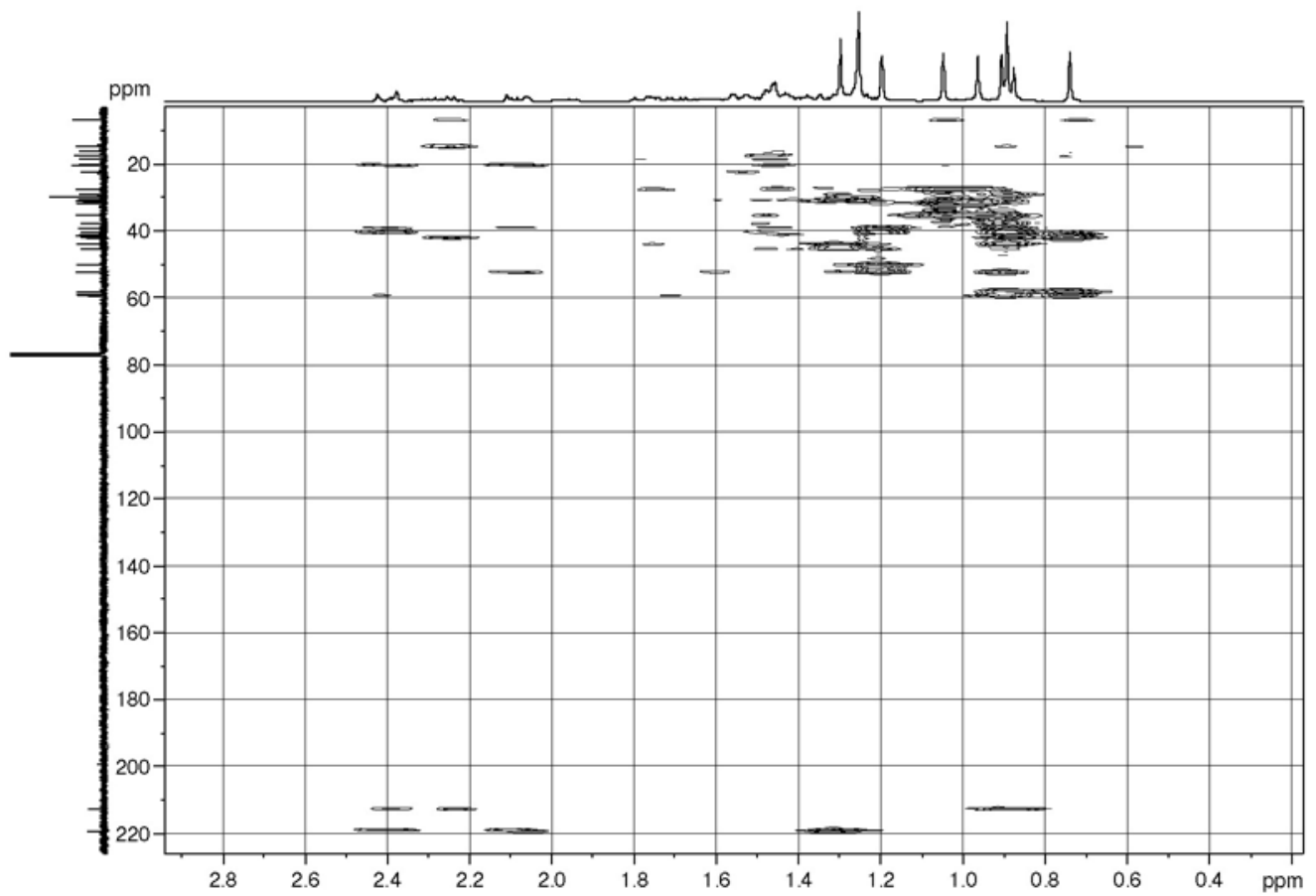

Figure S22. HMBC spectrum of compound $\mathbf{5}\left(\mathrm{CDCl}_{3}, 400 \mathrm{MHz}\right)$. 


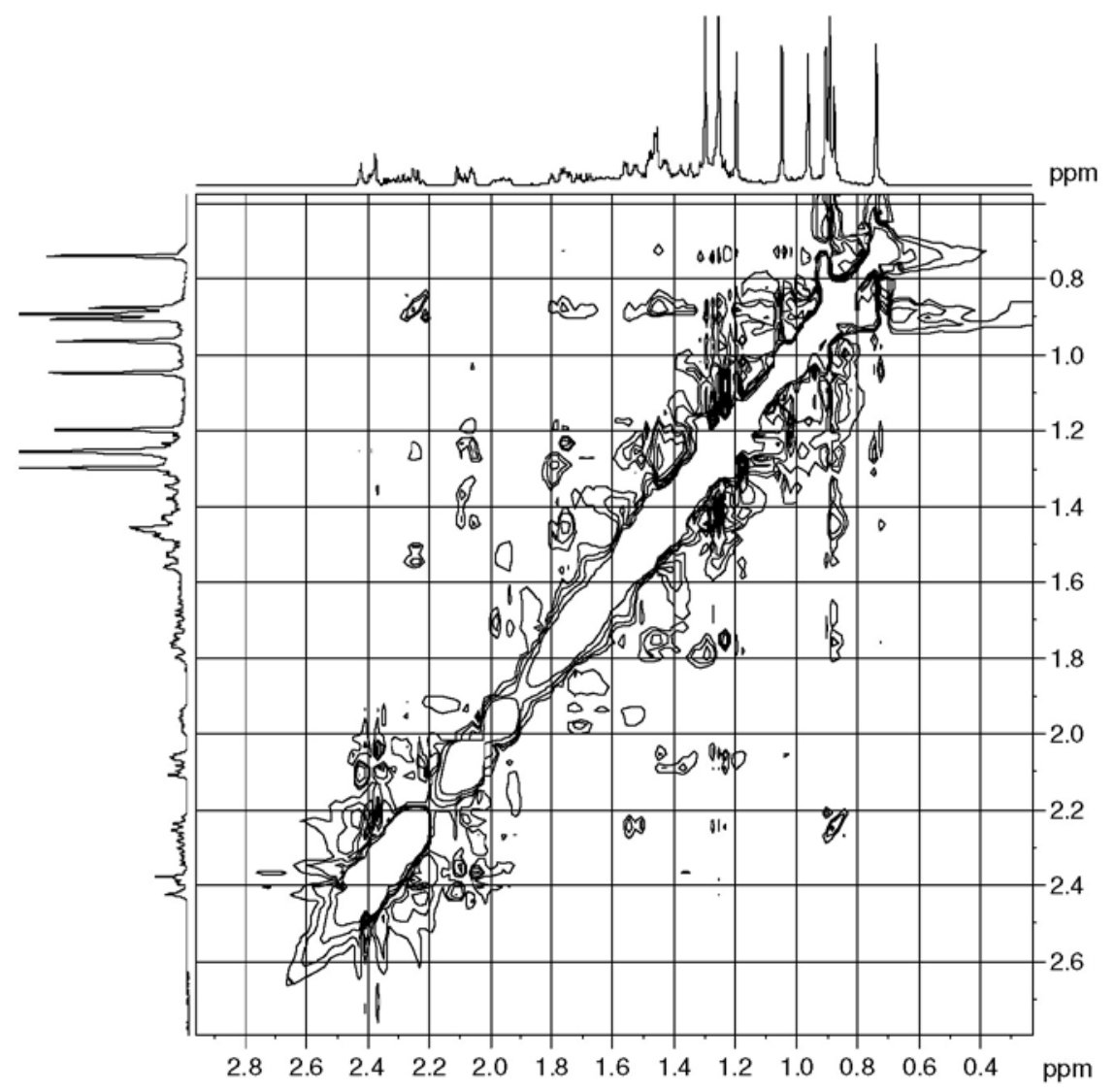

Figure S23. ${ }^{1} \mathrm{H}$, ${ }^{1} \mathrm{H}$ NOESY spectrum of compound $\mathbf{5}\left(\mathrm{CDCl}_{3}, 400 \mathrm{MHz}\right)$.

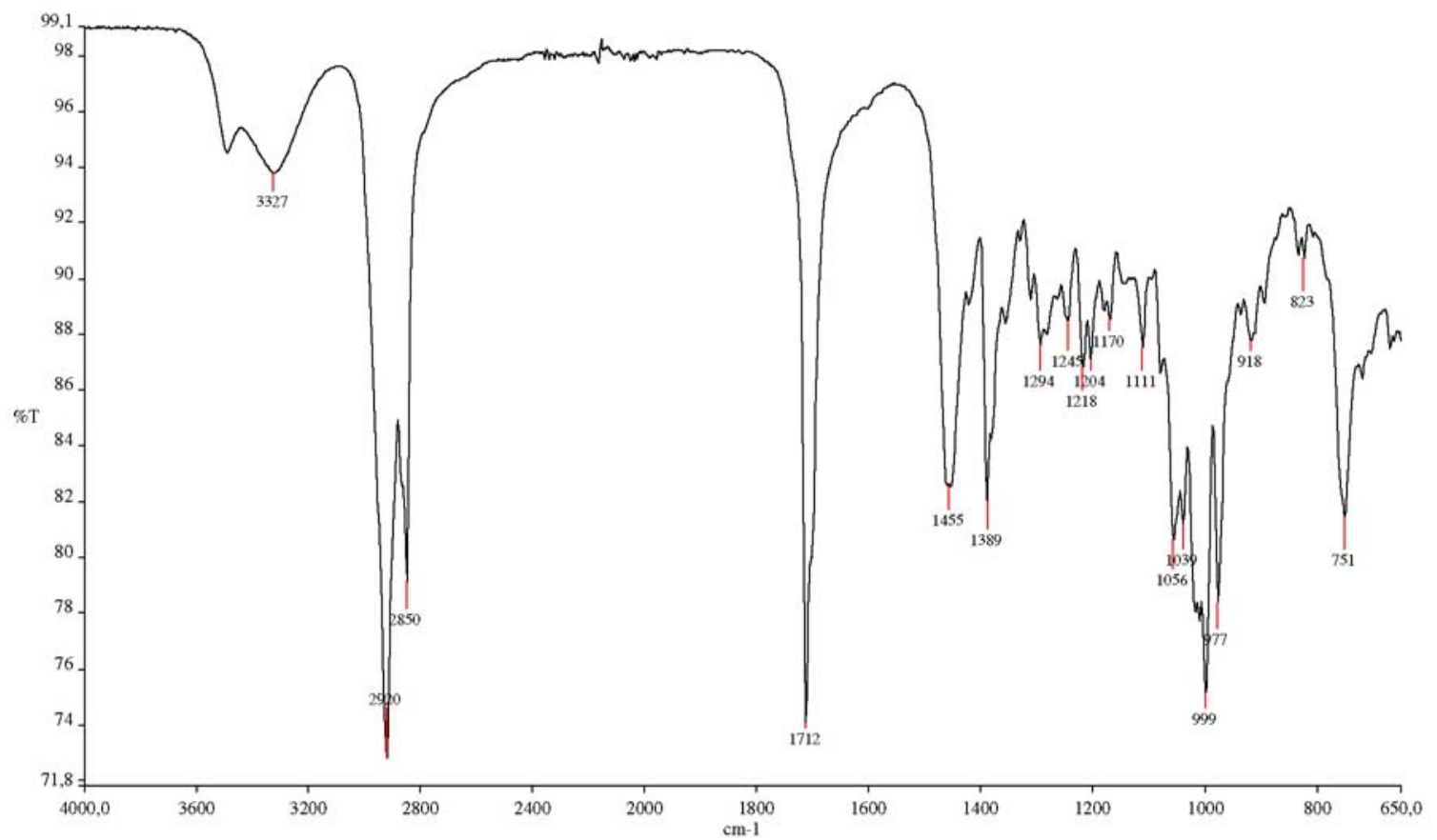

Figure S24. IR spectrum of compound 6 (ATR). 


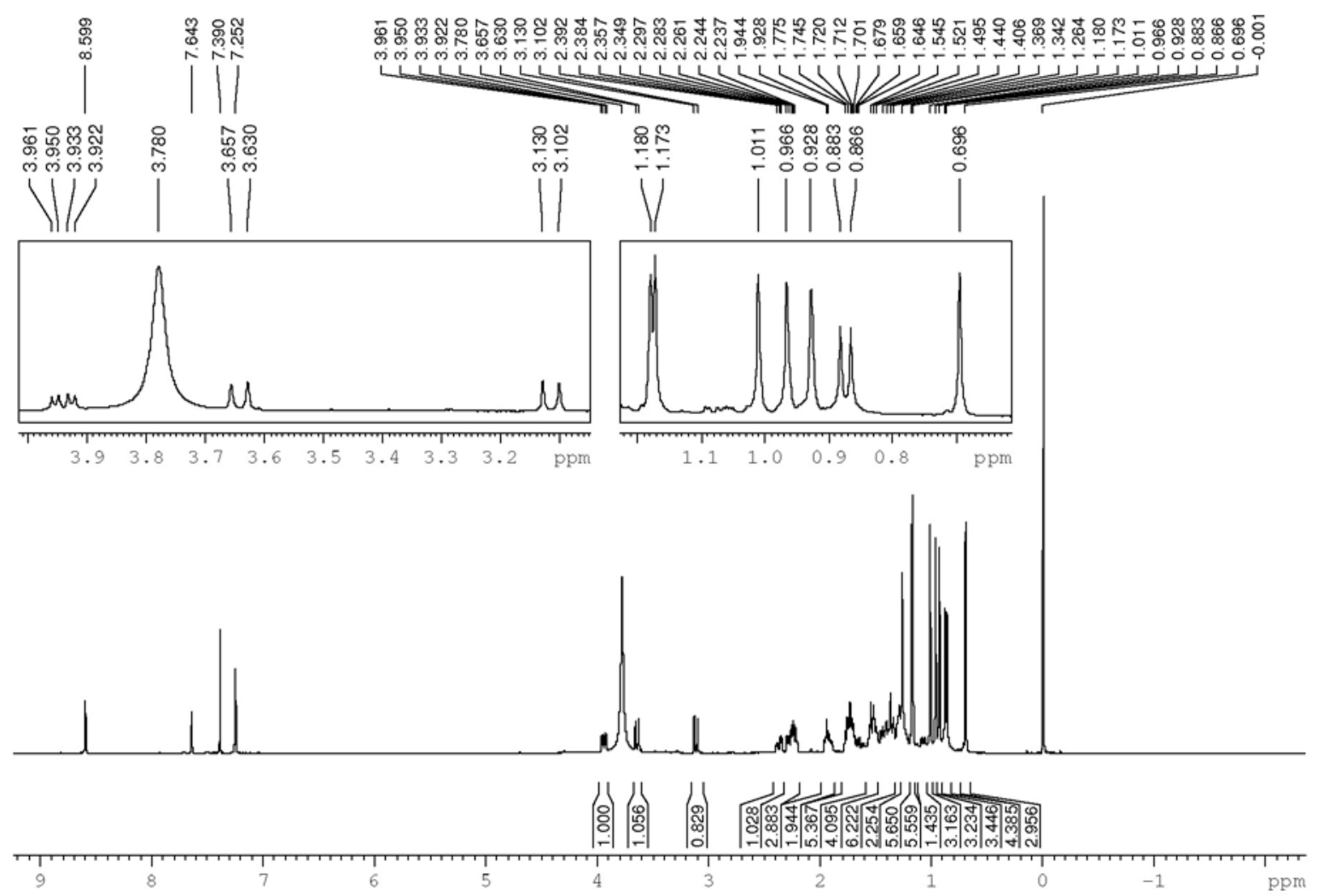

Figure S25. ${ }^{1} \mathrm{H}$ NMR spectrum of compound $6\left(\mathrm{CDCl}_{3}+\right.$ pyridine- $\left.d_{5}, 400 \mathrm{MHz}\right)$.

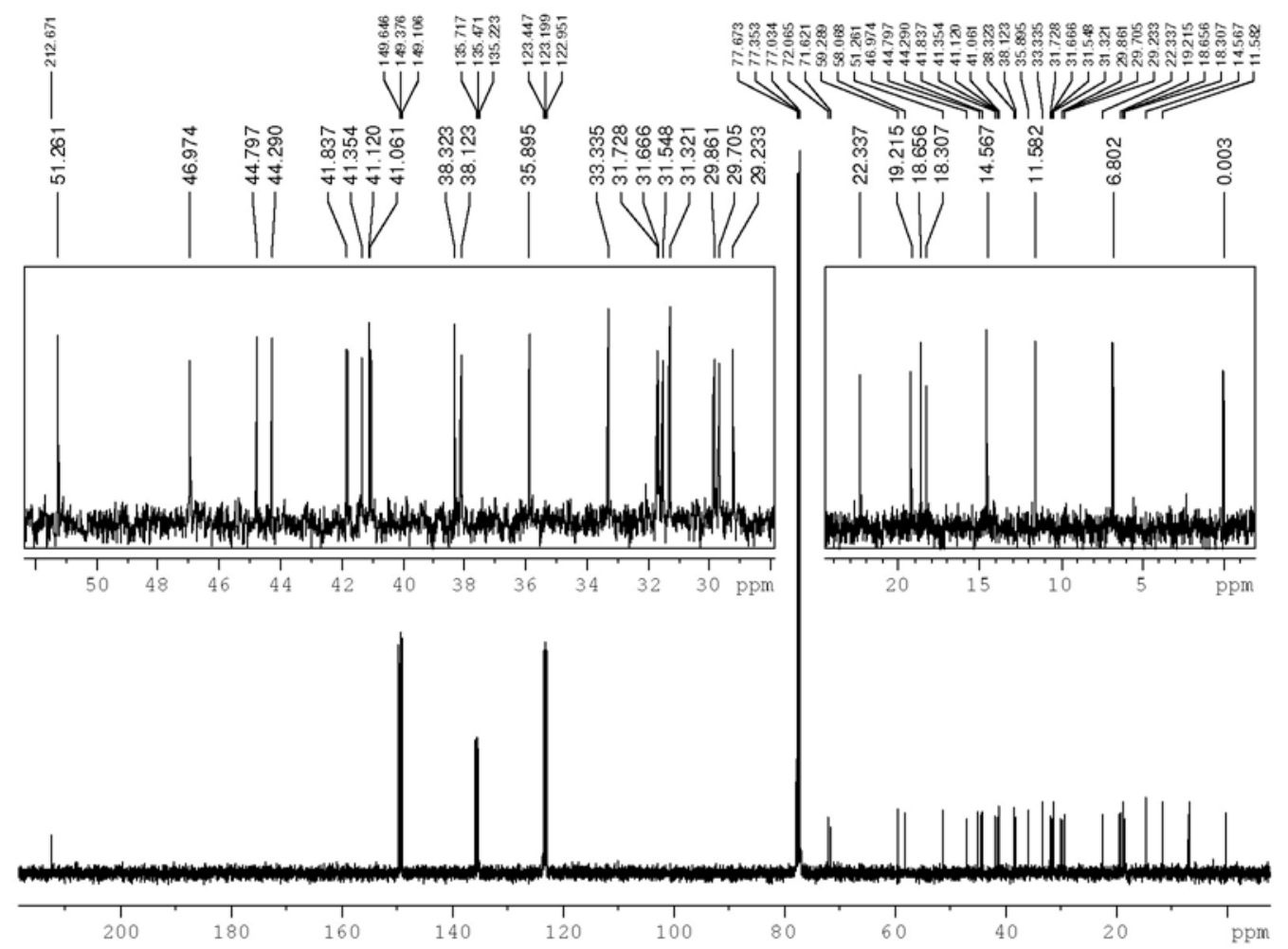

Figure S26. ${ }^{13} \mathrm{C}$ NMR spectrum of compound $6\left(\mathrm{CDCl}_{3}+\right.$ pyridine- $\left.d_{5}, 100 \mathrm{MHz}\right)$. 


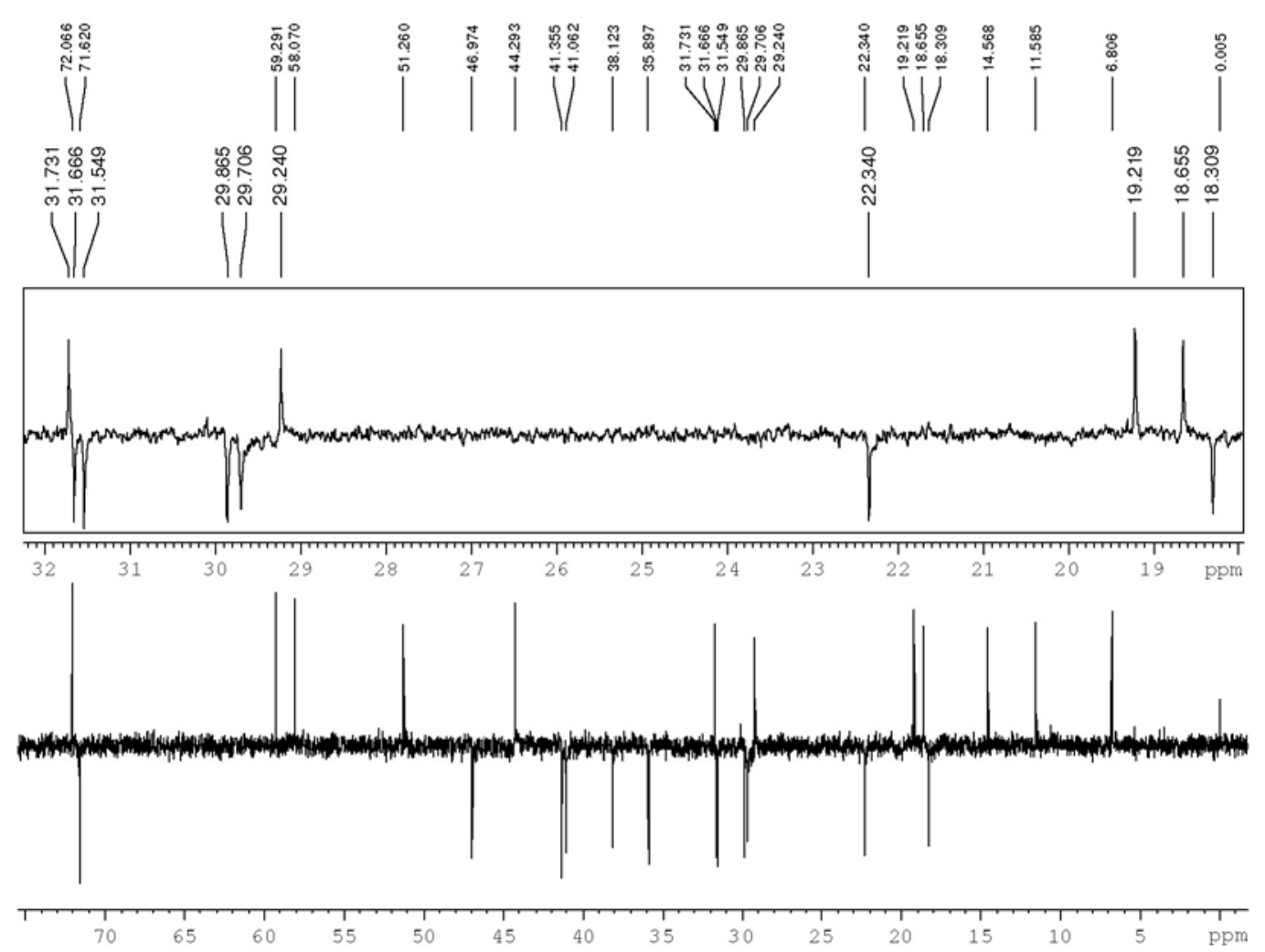

Figure S27. ${ }^{13} \mathrm{C}$ NMR-DEPT spectrum of compound $6\left(\mathrm{CDCl}_{3}+\right.$ pyridine- $\left.d_{5}, 100 \mathrm{MHz}\right)$.

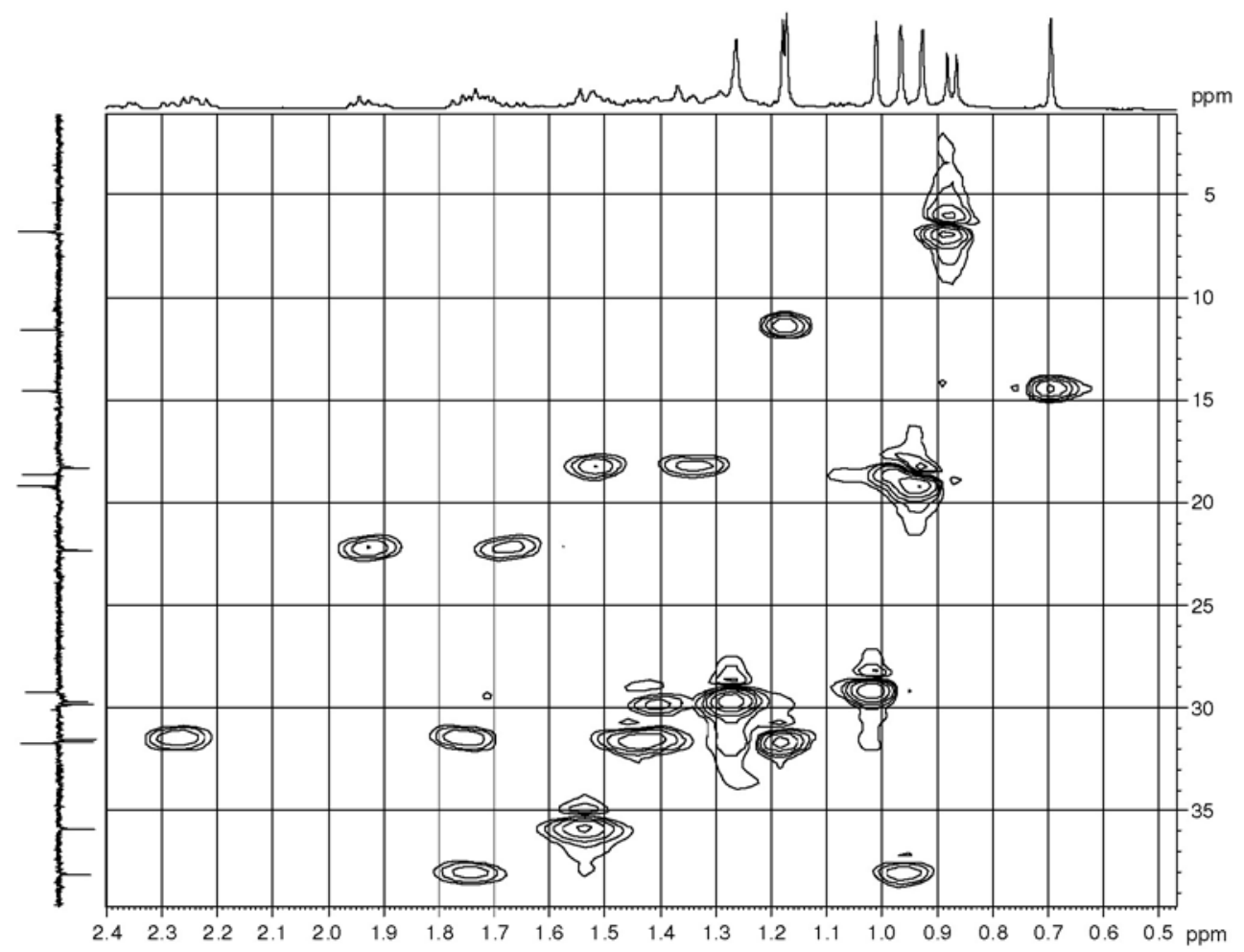

Figure S28. First expansion of HSQC spectrum of compound $6\left(\mathrm{CDCl}_{3}+\right.$ pyridine- $\left.d_{5}, 400 \mathrm{MHz}\right)$. 


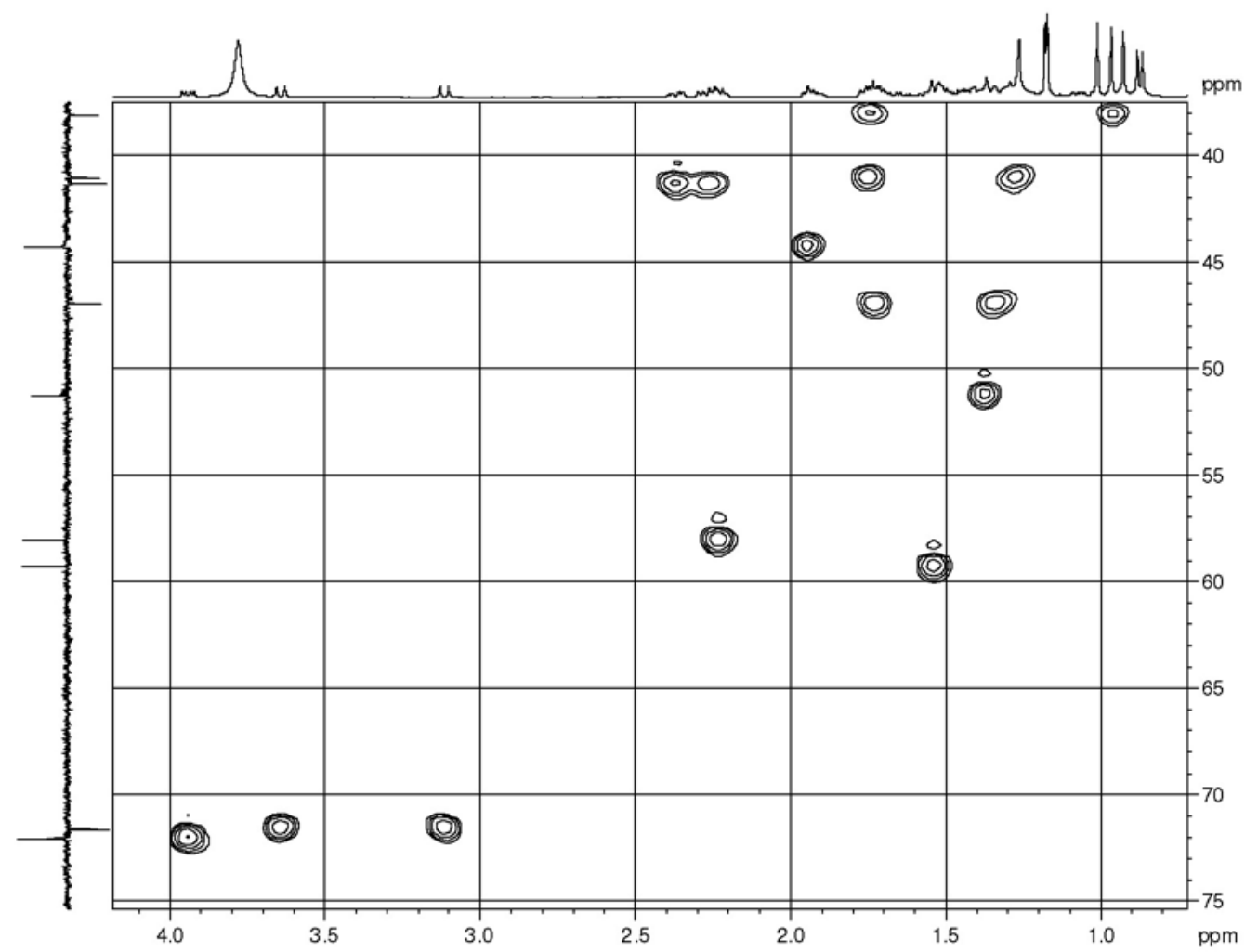

Figure S29. Second expansion of HSQC spectrum of compound $6\left(\mathrm{CDCl}_{3}+\right.$ pyridine- $\left.d_{5}, 400 \mathrm{MHz}\right)$.

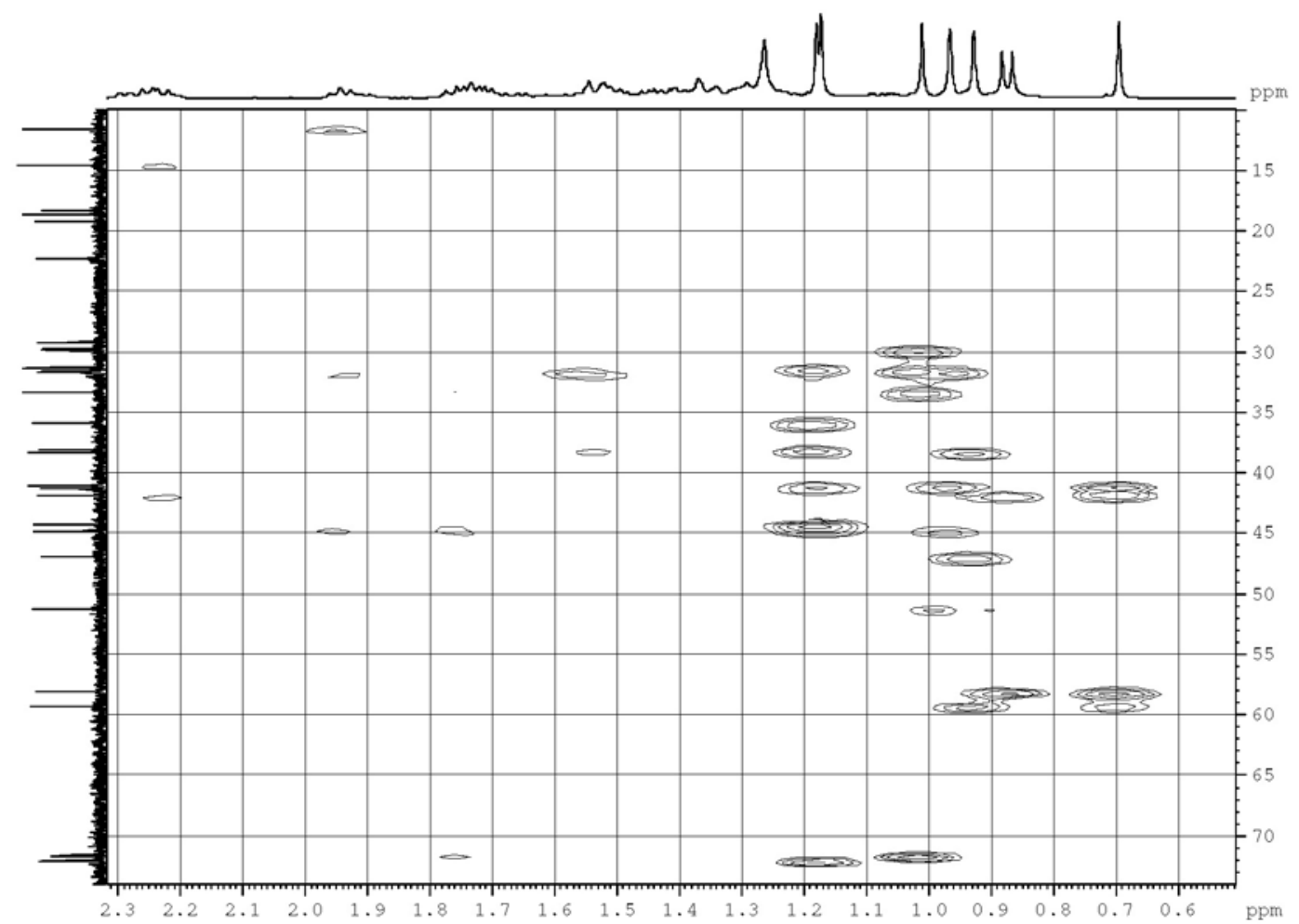

Figure S30. First expansion of HMBC spectrum of compound $6\left(\mathrm{CDCl}_{3}+\right.$ pyridine- $\left.d_{5}, 400 \mathrm{MHz}\right)$. 


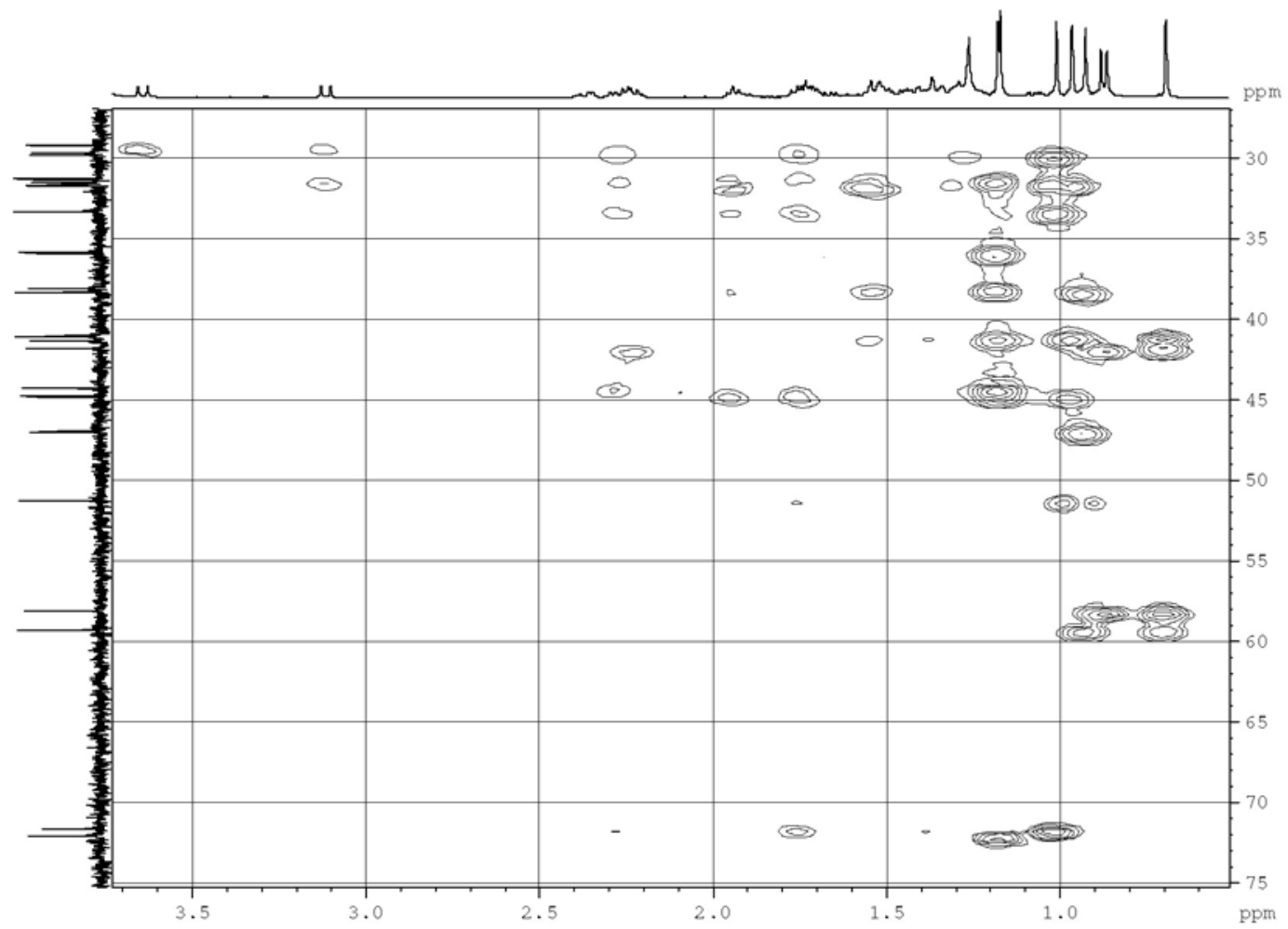

Figure S31. Second expansion of HMBC spectrum of compound $6\left(\mathrm{CDCl}_{3}+\right.$ pyridine- $\left.d_{5}, 400 \mathrm{MHz}\right)$.

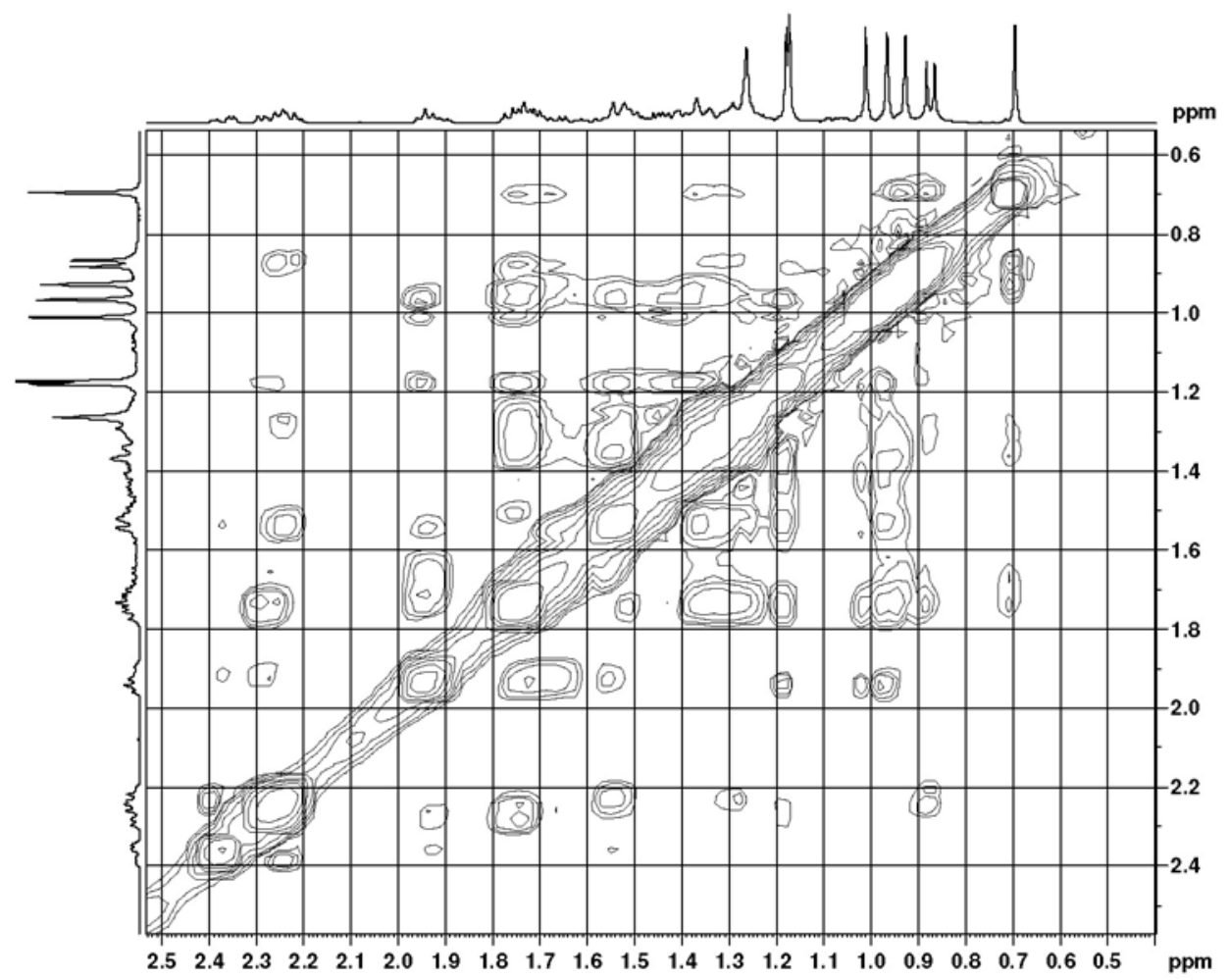

Figure S32. First expansion ${ }^{1} \mathrm{H},{ }^{1} \mathrm{H}$ NOESY spectrum of compound $\mathbf{6}\left(\mathrm{CDCl}_{3}+\right.$ pyridine- $\left.d_{5}, 400 \mathrm{MHz}\right)$. 


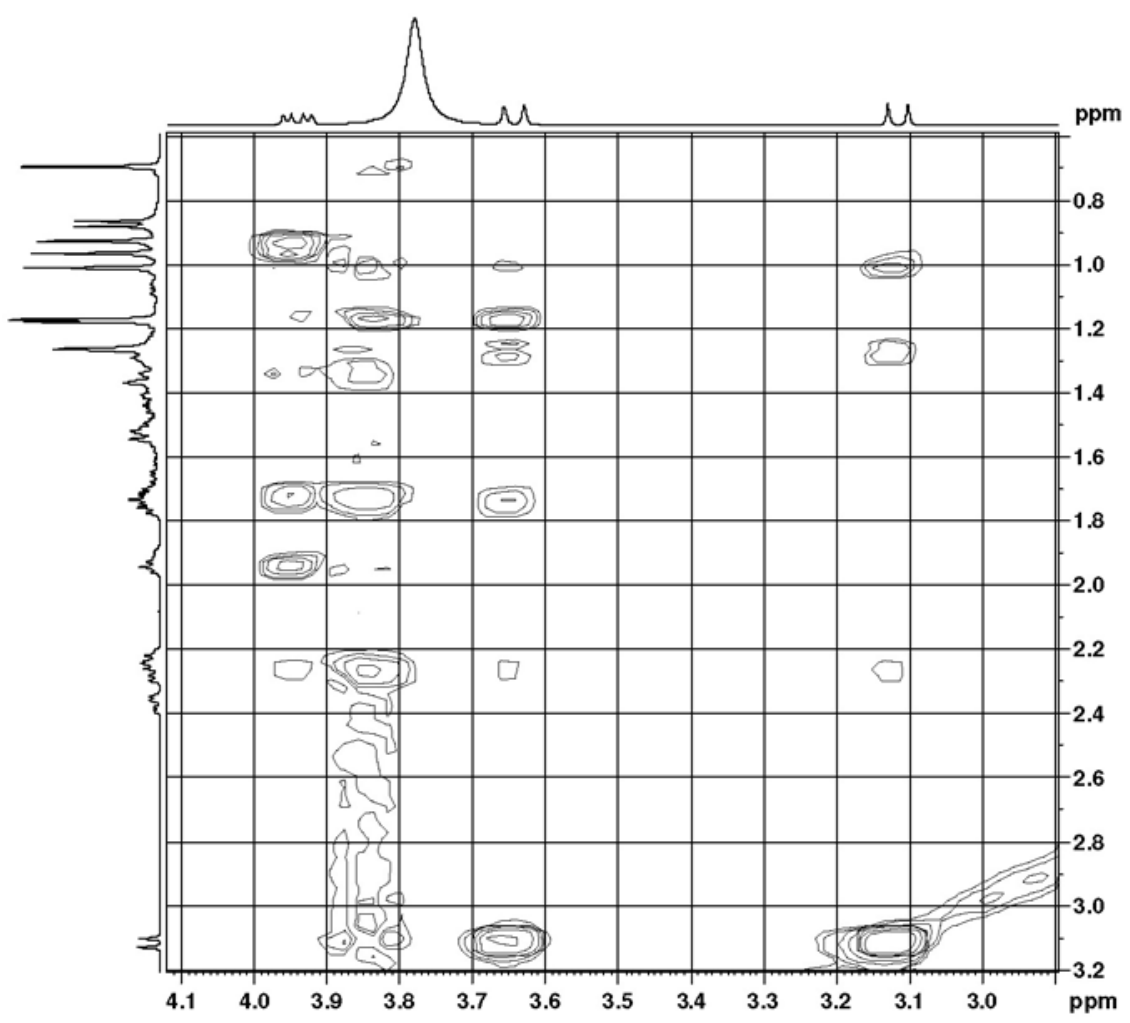

Figure S33. Second expansion ${ }^{1} \mathrm{H},{ }^{1} \mathrm{H}$ NOESY spectrum of compound $6\left(\mathrm{CDCl}_{3}+\right.$ pyridine- $\left.d_{5}, 400 \mathrm{MHz}\right)$.

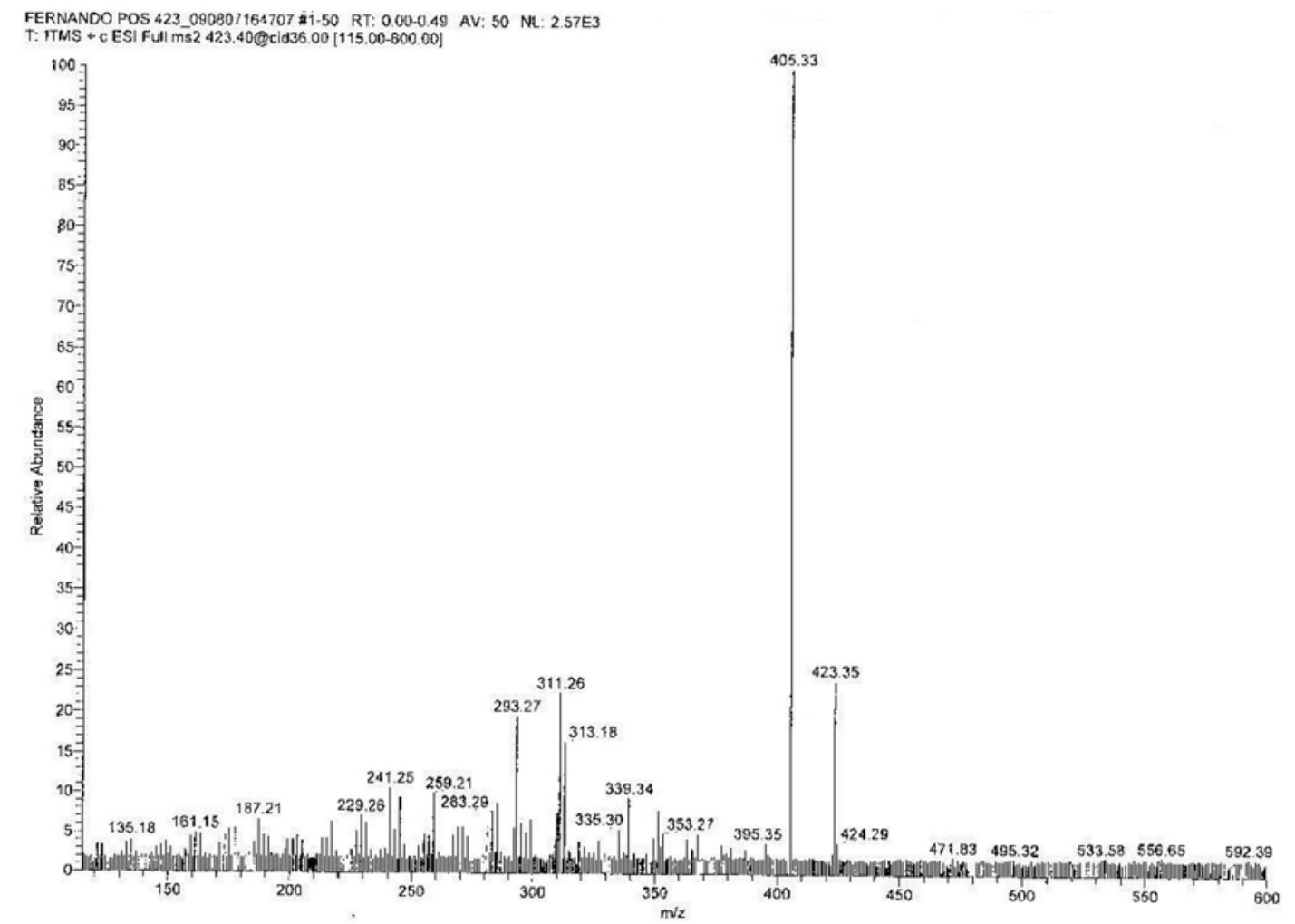

Figure S34. ESI-mass spectrum of compound 6 . 